Recurring Dreams and Moving Images: The Cinematic Appropriation of Schumann's Op. 15, No. 7

Author(s): Jeremy Barham

Reviewed work(s):

Source: 19th-Century Music, Vol. 34, No. 3 (Spring 2011), pp. 271-301

Published by: University of California Press

Stable URL: http://www.jstor.org/stable/10.1525/ncm.2011.34.3.271

Accessed: 18/11/2011 09:55

Your use of the JSTOR archive indicates your acceptance of the Terms \& Conditions of Use, available at http://www.jstor.org/page/info/about/policies/terms.jsp

JSTOR is a not-for-profit service that helps scholars, researchers, and students discover, use, and build upon a wide range of content in a trusted digital archive. We use information technology and tools to increase productivity and facilitate new forms of scholarship. For more information about JSTOR, please contact support@jstor.org.

University of California Press is collaborating with JSTOR to digitize, preserve and extend access to 19thCentury Music. 


\title{
Recurring Dreams and Moving Images: The Cinematic Appropriation of Schumann's Op. 15, No. 7
}

\author{
JEREMY BARHAM
}

\section{EARLy Cinema AND The "TräUmereI" PhenOMENON}

When audiences at Chicago's Senate Theater in 1909 heard Schumann's "Träumerei" played as part of the musical accompaniment to the "highly dramatic" Biograph film A Fool's Re-

\footnotetext{
I am grateful to Laura Tunbridge and the anonymous reviewers for their helpful comments on earlier versions of this article. I also extend thanks to Reinhard Kapp, Rufus Hallmark, Annette Kreutziger-Herr, Arnfried Edler Bernhard Appel, Beate Perrey, Janina Klassen, and David Ferris for generously responding to various queries in relation to Schumann, Clara, and Ludwig Rellstab.
}

My heart leaps up when I behold

A rainbow in the sky:

So was it when my life began;

So is it now I am a man;

So be it when I shall grow old, Or let me die!

The Child is father of the Man;

I could wish my days to be Bound each to each by natural piety.

-Wordsworth, 1802

You must not seek to add To what you have, what you once had;

You have no right to share What you are with what you were.

No one can have it all, That is forbidden.

You must learn to choose between. -Afanas'yev/Ramuz/Stravinsky, 1918

America only makes children's pictures. -John Hurt, n.d.

venge, ${ }^{1}$ they were witnessing not only an emergent trend in film presentation toward increasingly sophisticated and generically wide-ranging musical characterization, but also a significant stage in the deracination and mass commoditizing of a familiar musical work. A reporter from Moving Picture World described his response to this early manifestation of the practice: "The film made a deep impression on the audience. . . . A pleasant variation from the

${ }^{1}$ Moving Picture World, 13 March 1909, cited in Charles Hofmann, Sounds for Silents (New York: DBS Publications, 1970), p. 9. 
eternal ragtime was a refined deliverance of classical music corresponding to the character of the picture, including Schumann's 'Traumerei' [sic] and Beethoven's 'Moonlight Sonata.' The first time, indeed, we ever heard Beethoven in a five-cent theatre." 2 The history, mechanics, and aesthetic repercussions of such screen appropriation of "Träumerei" will concern me in this study (ex. 1).

Rick Altman has shown that conflicting forces were at work in these early years of film music and film sound from ca. 1910. On the one hand, there was the polarization of film genre, class perceptions, and musical style in which "popular songs were limited to comedies, while classical selections were reserved for drama" and "arbiters of musical taste increasingly associated class and prestige exclusively with European (or European-sounding) music. ${ }^{\prime 3}$ On the other hand, there was the rapid commercial solidification of the signifying potential of an initially small number of familiar works. Here "Träumerei" took its place alongside comparable Romantic mood snapshots by Gounod, Mendelssohn, Rubinstein, Weber, Donizetti, Offenbach, Suppé, Verdi, and Wagner. ${ }^{4}$

It was not long, however, before these generic and class distinctions became blurred, and the resources for screen accompanimentwhether performed on piano, organ, or by instrumental ensembles of varying sizes-expanded beyond all previous recognition. Carli Elinor's compilation score for Griffith's film The Clansman (1915) comprised commonly used works by Beethoven, Bizet, Flotow, Massenet, Mozart, Offenbach, Rossini, Schubert, Suppé, Verdi, and Wagner played by an ensemble

\footnotetext{
${ }^{2}$ Ibid. Roger Manville and John Huntley cite the significant but frustratingly vague description by Cecil Hepworth, one of the United Kingdom's first film pioneers, of his traveling exhibition from an even earlier time in the 1890s: "I remember one little series which always went down very well indeed. It was called The Storm and consisted of half a dozen slides and one forty-foot film. My sister Effie was a very good pianist and she travelled with me on most of these jaunts. The sequence opened with a calm and peaceful picture of the sea and sky. Soft and gentle music (Schumann, I think)" (The Technique of Film Music [London: Hastings House, 1957], p. 20).

${ }^{3}$ Rick Altman, Silent Film Sound (New York: Columbia University Press, 2004), p. 267.

${ }^{4}$ Ibid., p. 313.
}

of forty players plus vocal soloists and chorus during its initial twenty-two-week run in Los Angeles. ${ }^{5}$ When the film reopened in New York later that year under its more familiar title The Birth of a Nation, Joseph Breil's new compilation score plundered and adapted, alongside twenty-six popular tunes and songs, the works of nine composers. ${ }^{6}$ Similarly, Frank Adams, the organist of the New York Rialto theater, together with conductor/arranger Hugo Riesenfeld, put together a score compiled from the works of nineteen composers (including excerpts from Schumann's Symphony No. 4, op. 120, and "Am Kamin" from Kinderszenen) for a 1922 presentation of Dr. Jekyll and Mr Hyde. ${ }^{7}$

Partly as a reflection of current practices, and partly to formalize and formularize those practices in prepackaged, ready-to-use, and commercially lucrative form, various publications emerged from the mid-1910s that acted to cement even further a lexicon of musical semantics, which, though direct and efficient in its

\footnotetext{
${ }^{5}$ Ibid., p. 292. Martin Marks lists the following: "The Clansman" Overture by J. E. Nurnberger, "Semiramide" Overture by Rossini, "Tancredi" Overture by Rossini, "Light Cavalry" Overture by F. V. Suppé, "Morning, Noon, and Night" Overture by F. V. Suppé, "Romantic" Overture by K. Bela, "Stradella" Overture by F. V. Flotow, "Marriage of Figaro" Overture by W. A. Mozart, "Orphée aux Enfers" (Violin solo interpreted by Miss Elsa Grosser) by J. Offenbach, "Nabucodonozar" by G. Verdi, "Sinfonia," Giovanna d'Arco by G. Verdi, "First Symphony" by L. V. Beethoven, "Unfinished Symphony" by F. Schubert, "Les Huguenots" by Meyerbeer, "Rienzi" by R. Wagner, "Le Jongleur de Notre Dame" by J. Massenet, "L'Arlésienne" (Prelude and Carillon) by G. Bizet, "Silent Woe" and "Anathema" by A. V. Fielitz, "Americana" Suite by W. Thurban,"Incidental," music selected by C. D. Elinor and L. Brown (Music and the Silent Film: Contexts and Case Studies, 1895-1924 [New York: Oxford University Press, 1997], p. 134)

${ }^{6}$ Marks lists the following: Beethoven, Symphony No. 6 (iv), Bellini, Norma (overture), Grieg, Peer Gynt Suite ("In the Hall of the Mountain King"), Hérold, Zampa Overture, Mozart, Twelfth Mass in G Major ("Gloria"), Suppé, Light Cavalry Overture, Tchaikovsky, 1812 Overture, Wagner, Rienzi (overture) and "Ride of the Valkyries," and Weber, Der Freischütz (overture) (ibid., pp. 208-09; see also pp. 135-66 and 198-218 for further details of the score). I am grateful to Martin Marks for clarifying the status of other less accurate, accounts of the music used in the Elinor and Breil compilations

${ }^{7}$ See Altman, Silent Film Sound, pp. 337-39. Arthur Kleiner musical director of the Film Department at the Museum of Modern Art from 1939, would later accompany presentations of Murnau's Faust (1926) with selections from Schumann's Scenes from Goethe's Faust (see Hofmann, Sounds for Silents, pp. 52-53).
} 

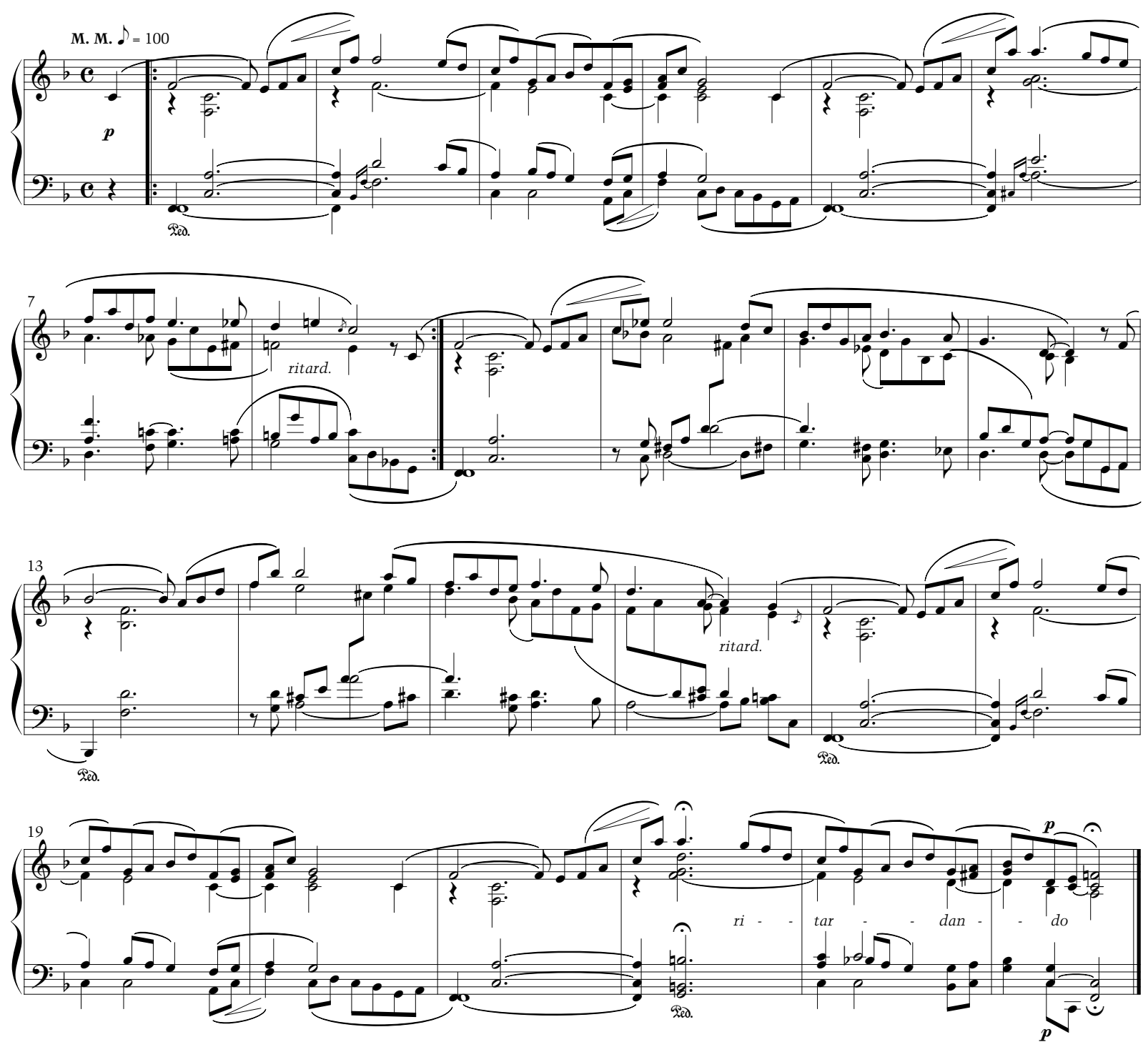

Example 1: Schumann's "Träumerei," op. 15, no. 7.

effect, risked being aesthetically limiting in its reliance on, and purveying of, a narrowing set of assumptions and attributions and a relentless impulse toward metonymical excerpting: for example, F.B. Haviland's Moving Picture Pianist's Album (1911), Carl Fischer Moving Picture Folio (1912), Ernst Luz's A.B.C. Dramatic Set (1915-20) and A.B.C. Feature PhotoPlay Edition (1917-19), John Zamecnik's Sam Fox Moving Picture Music (1913-14) and Sam Fox Photoplay Edition (1919-22), and, last but not least, Erno Rapée's Motion Picture Moods for Pianists and Organists (1924). As an illus- tration of Schumann's clear presence in the creative minds, practices, and printed collections of this time, Luz's A.B.C. Dramatic Set, no. 10, designed for a "Diabolical Scene," comprises a "Heavy Misterioso" composed by Luz and two pieces "adapted from Shumann's [sic] Childhood Scenes," which are in fact versions of "Knecht Ruprecht" and "Volksliedchen" from Album für die Jugend, op. 68 (correct attribution and fidelity to authorial ownership were low priorities). As Max Winkler, manager of the Moving Picture Music Department of Carl Fischer publishers and possible inventor 
of the cue sheet, later famously wrote in an oftquoted passage: "We began to dismember the great masters . . . extracts from great symphonies and operas were hacked down to emerge again as 'Sinister Misterioso'. . . . If they were to be used for happy endings we jazzed them up mercilessly. Finales from famous overtures ... became gallops." ${ }^{8}$ The operatic-soprano-turnedstar-actress Geraldine Farrar ${ }^{9}$ compiled her own list of appropriate music for screen moods ranging from contentment (Debussy, Prélude à "L'Après-midi d'un faune") to anger (Schubert, Erlkönig) and from despair (Leoncavallo, "Vesti la giubba") to delight (Schumann, Carneval [sic]), ${ }^{10}$ while the New York Dramatic Mirror film-music columnist Montiville Morris Hansford recommended Schumann in his shortlist of keyboard composers whose music was particularly suitable for film accompaniment. ${ }^{11}$ After listing a host of well-known popular tunes used for Irish films, tearjerkers, or war pictures, Bert Ennis (publicity assistant at the Vitagraph Studios in New York and one of many who claimed to have invented the cue sheet) wrote the following about his activities in 1910, implying that "Träumerei" had by this stage already become staple household fare:

We showed our class by injecting at times the classical and standard numbers-a few of them anyhow. "Hearts and Flowers," "Melody in F," "Träumerei," "Souvenir," "Pilgrims' Chorus,"- - they all helped to give helpless audiences a barrage of highbrow music before the present day experts in the writing of music scores for films discovered Debussy, Beethoven, Schubert, Mozart, Wagner and other big leaguers of the classical field. ${ }^{12}$

\footnotetext{
${ }^{8 " T h e ~ O r i g i n ~ o f ~ F i l m ~ M u s i c, " ~ F i l m s ~ i n ~ R e v i e w ~ 2 / 34 ~(D e c . ~}$ 1951), cited in Altman, Silent Film Sound, p. 361.

${ }^{9}$ Farrar made her film debut as Carmen in Cecil B. DeMille's 1915 film of that name. According to the IMDb, when acting, she "demanded a pianist and a violinist on the set to provide mood music, a string trio for especially dramatic scenes" (http://www.imdb.com/name/nm0268125/ bio).

${ }^{10}$ Curtis Dunham, "Musical Anaesthesia for Motion Picture Audiences," Metronome (Feb. 1921), 72, cited in Altman, Silent Film Sound, pp. 368-69.

11"Preparing Music for Photoplay Accompaniments," New York Dramatic Mirror (29 Sept. 1917), 9, cited in Altman, Silent Film Sound, p. 429.

${ }^{12}$ Cited in Hofmann, Sounds for Silents, p. 15.
}

In Rapée's encyclopedic compilation, subtitled "A Rapid-Reference Collection of Selected Pieces Adapted to Fifty-Two Moods and Situations," Schumann is listed four times: under "Funeral" ("Andante Pathétique no. 1," a keyboard arrangement of the opening C-minor section of the second movement, "In Modo d'una Marcia," of the Piano Quintet, op. 44);13 "Hunting" ("Jagdlied," op. 82 and "Jägerliedchen" [op. 68]); and, injecting a moral dimension (no doubt rooted in ready acceptance of childhood contexts and legacies) into possible filmic characterizations through music, "Quietude and $\mathrm{Pu}$ rity" ("Träumerei," op. 15, no. 7). ${ }^{14}$ The number of listings by Rapée of other composers is: Grieg (20), Mendelssohn (10), Beethoven and Bizet (6), Johann Strauss (5), Schubert and Chopin (4), Tchaikovsky (3), Delibes, Dvořák, Fibich, Rubinstein, Wagner (2), and Boccherini, Brahms, Elgar, Glazunov, Handel, Liadov, Massenet, Meyerbeer, Offenbach, Paderewski, and Sullivan (1).

Embedding standardized associative meanings for the film viewer through regular exposure to familiar musical repertoire in this way was initially very effective, but already by 1915 and 1918 Luz and the film-music columnist George Beynon were respectively questioning the extent to which this led to a kind of aesthetic exhaustion and emotional desiccation. Luz, significantly, makes reference to the piece under investigation here: "We might call Schumann's 'Traumerei' [sic] a number with a positive pathetic appeal, and use it at all times when screen action is of a pathetic character, could we hope that the audience would enjoy its third or fourth repetition in one hour?"15 Beynon comments in a general sense:

The orchestra opens the picture with a beautiful number. . . . The music changes. In a few minutes the first selection is played again. It's a nice number. Two or three short numbers intervene and you hear

\footnotetext{
${ }^{13}$ Notably Clara Schumann had made a piano-duet arrangement of the op. 44 Quintet in 1858.

${ }^{14}$ Erno Rapée, Motion Picture Moods for Pianists and Organists (New York: G. Schirmer 1924), pp. v, vi, and xi (my emphasis).

${ }^{15}$ Luz, "Theme Playing as Used and Abused" in "Music and the Picture," Moving/Motion Picture News (14 Aug. 1915), 130, cited in Altman, Silent Film Sound, p. 376.
} 
it again. It's a fair number. An agitato follows, it is repeated and becomes a monotonous number. The third reel is being shown, and again you hear it. You cannot understand why they play it so much. It palls. As the music continues, this poor little number is dragged in by the heels . . . until your soul rebels and you hate that music forever. ${ }^{16}$

By the time cinema had taken hold of Schumann's "Träumerei," it was already too late for this kind of musical typecasting to be counteracted, for the long-standing nineteenth-century fashion for making and performing arrangements of this piece had also been reaching a peak, rendering its assumption into screen culture something of an inevitability. Károly Csipák and Reinhard Kapp reproduce the score of an arrangement for piano and harmonium published by Carl Simon in Berlin (dating from the turn of the twentieth century), whose cover page also lists a wide range of alternative published versions scored for the following combinations-a "Träumerei" package to suit all requirements:

Piano (two- and four-hand)

Harmonium (or organ) solo

Flute (violin or cello), harmonium and piano

Flute (or violin) and harmonium

Flute (or violin) and piano

Cello (or viola) and harmonium

Cello (or viola) and piano

Two violins and piano

Cornet à pistons in $\mathrm{B} b$ and piano

Harmonium (or organ) and string quintet (or quartet)

Piano, harmonium and string quartet

Salon orchestra (piano, violin (violin II or viola) cello, flute, cornet à pistons (harmonium ad lib.)

Trio for piano, violin and cello

Piano four-hands, violin and cello (flute, cornet and harmonium ad lib.)

Violin and harmonium

Violin and piano

Grand organ (freely adapted by Karg-Elert) ${ }^{17}$

With a clear agenda that denigrates as kitschy distortion such (re)arrangement and its result-

${ }^{16}$ George Beynon, "Proper Presentation of Pictures Musically: The Theme," Moving Picture World (23 Feb. 1918), 1093, cited in Altman, Silent Film Sound, p. 376.

17"'Träumerei'," Musica 35/5 (Sept.-Oct. 1981), 438-43; quotation p. 441. ing challenges to the hallowed origins of the musical work, they write:

The history of "Träumerei"'s disfigurement . . . can be traced in popular nineteenth-century arrangements. ... In addition to the various salon- and coffee-house re-workings, there also exist orchestral, choral, song and vocalise versions of "Träumerei." Soviet balalaika ensembles have been heard to play it, and doubtless guitar, mouth-organ, and accordion groups too. The effects of this practice should not be underestimated. . . The interpreters are no longer playing the work but rather a rumour of it, its ubiquitous caricature. ${ }^{18}$

To some extent supporting this claim, the $\mathrm{Mu}$ sical Times and its predecessor, the Musical Times and Singing Class Circular, list a significant number of performances (and, later, recordings) of the work in the United Kingdom and the United States (in isolation and in a variety of orchestral, string ensemble, solo violin, and cello arrangements) in the 1880s and 1890 s, but then virtually none until the 1920 s and 1930s. ${ }^{19}$ Could it have been that the intervening culture of silent screen appropriation had helped to revitalize a then-waning tradition of concert interest in the piece? With this combination of the renewal of a strong performance legacy stretching back to a period not long after the composer's death and an equally robust recent history of early-twentieth-century silent screen cultural absorption, it was not surprising that this work, described by Kapp as having "determined the image of Schumann and the conception of [his] music for generations," should continue to have been called upon in the world of the sound film. Nevertheless, arrangements of the piece-the "succes-

\footnotetext{
${ }^{18}$ Ibid., p. 442.

${ }^{19}$ See vols. 22/465 (1 Nov. 1881), 570-71, 24/490 (1 Dec. 1883), 663-64, 30/554 (1 Apr. 1889), 218, 32/586 (1 Dec. 1891), 728, 33/592 (1 June 1892), 346, 33/598 (1 Dec. 1892), 726-27, 35/614 (1 Apr. 1894), 240-41, 36/625 (1 Mar. 1895), 184, 39/659 (1 Jan. 1898), 24-25, 51/807 (1 May 1910), 332, 62/942 (1 Aug. 1921), 571, 73/1070 (1 Apr. 1932), 330-31, 73/1073 (1 July 1932), 629. See also Eckhard John, "Musik und Konzentrationslager: Eine Annäherung," Archiv für Musikwissenschaft 48/1 (1991), 1-36, for reference to a poignant diary entry for 12 December 1943 by Arthur Haulot, a prisoner in the Dachau concentration camp, noting an afternoon concert that included a "deeply emotional" cello performance of "Träumerei."
} 
sive new guises," the "new clothes" that were "tailored according to those changing conceptions"20-were one thing. But the kinds of extreme adaptation, fragmentation, recontextualizing, and commercial exploitation of the work (and those of many other composers) that were to take place in the era of sound cinema challenged the terms of a conventional reception history of music founded simply on concert or recorded performance and its associated critical apparatus..$^{21}$ In the latter contexts, Kapp may be correct to judge that "Träumerei" no longer retains its turn-of-the-century prominence, but in other creative arenas such as that of twentieth- and twenty-first-century screen repertoire it has attained something of a second-if arguably somewhat interpretatively depleted-life. This new existence poses many difficult questions pertaining to aesthetic legitimacy, authorial presence, the culture of childhood, musical intimations of meaning, and the very nature of Romantic art and fantasy-questions whose exploration may compel us to reevaluate our relationship with this music. Therefore my aims here are to disentangle and interpret the knotty historical, cultural, and aesthetic encounter between Schumannian Romanticism and later (primarily Anglo-American) mass-media screen entertainment, and thereby to shed light on the wider creative practice of employing preexistent music in screen contexts.

\section{Schumann, Children's Music, and Cultural Economies}

Recourse by Luz, Adams, and Rapée to items from Schumann's Album für die Jugend and Kinderszenen for silent-film accompaniment is significant, but not surprising. The early life of the medium, coupled with the cultural sensibilities of the time, required, among other things, the kind of direct and efficient simplic-

\footnotetext{
${ }^{20}$ Reinhard Kapp, "Schumann in His Time and Since," in The Cambridge Companion to Schumann, ed. Beate Perrey (Cambridge: Cambridge University Press, 2007), pp. 22351; quotations p. 248.

${ }^{21}$ It is possible that Schumann's music was used in the presentation of live theatrical melodramas during the latter part of the nineteenth century, and in so far as such dramatic forms may be considered precursors to cinema it would be worthwhile investigating evidence for this.
}

ity seemingly offered by this music in order to supply the ostensibly clear-cut emotional and dramatic signification necessary for the mass communication of ideas. The employment of this music for such purposes seemed largely oblivious to the subtle qualitative distinction between works composed for children and works composed "about" childhood, however much Schumann's own often-quoted differentiation between the two collections has been left unchallenged. (Purely technical demands aside, the adult craftsman hand of the composer is very much in evidence across these pieces.) Schumann, at least the publicly adopted Schumann of Kinderszenen, shared with certain dominant areas of earliest silent-film culture a Wordsworthian acknowledgment of the pure, naïve yet earnest child that eternally exists within, and is variously reimagined by, every adult-a utopian sentiment poeticized in the quotation cited at the head of this article. What might appear to set Schumann apart from later film is a post-First-World-War sociocultural paradigm shift-intimated by the famous moral of Stravinsky's Soldier's Tale also cited abovetoward the recognition that there were limits to the viability of this psychological integration, and that accordingly things could, and perhaps should, no longer be the same as they had been before. This world seemed to have lost forever qualities of supposed innocence (or the ability to connect with such qualities), which initially would be submerged by extremes of Expressionist dystopia or absurd and cynical humor (for example, in Dada and Surrealist art, and populist screen cartoon genres with similar aesthetic agendas), and by the sophisticated screen works of the "new morality":22

The differences between Sennett's conception of comedy [through Fatty Arbuckle] and Harold Lloyd's, or between Mary Pickford's embodiment of feminine identity and Theda Bara's, or between the value systems of The Birth of a Nation (1915) and DeMille's Male and Female (1919), suggest the dimensions of the change that had occurred within sectors of the American public.

\footnotetext{
${ }^{22}$ See David A Cook, A History of Narrative Film (3rd edn. New York: W. W. Norton, 1996), pp. 214-25 for further discussion of this paradigm shift.
} 
An emphatic break with (and often critique of) the past and a self-conscious embrace of the modern characterized the post-war scene. . . . Post-war Europe quickly defined the modern within an older, élitist, and highly intellectualized aesthetic sensibility. . . . But the modern as manifest in American mass culture ... embodied democratic appeal, instant gratification, and seamless illusionism. . . . Hollywood's modernism inhered in the industrialized creation of products driven by the project of telling stories as efficiently and transparently as possible ... and the persistence throughout the west of the signifying practices associated with Hollywood would characterize the decades to come. ${ }^{23}$

That this shift was embedded in contexts of late-Industrial-revolution economics nevertheless masked a deeply repressed nostalgia-a sense of brokenness that formed one of the essential foundations of the Freudian psychoanalytic project. ${ }^{24}$ After all, in the early postwar years there still existed a strong vein of sentimentalized film melodrama and homespun romance that employed "the uncomplicated narrative montage of Griffith's prewar films, "25 and it could be argued that despite its diversifying developments in other technical and aesthetic areas, mainstream cinema has never quite outgrown these tendencies. Whereas conflicting assessments of the make-up of early-twentieth-century vaudeville, nickelodeon, and picture-palace clientele make it difficult to map these developments straightforwardly onto a class-oriented "bourgeoisification of cinema"

\footnotetext{
${ }^{23}$ William Uricchio, "The First World War and the Crisis in Europe," in The Oxford History of World Cinema, ed Geoffrey Nowell-Smith (Oxford: Oxford University Press, 1997), pp. 62-70; quotation p. 70

${ }^{24}$ That this same sentiment formed the basis of Adorno's Mahler critique is significant: "the late works embody a Romanticism of disillusionment . . . [Mahler's] Utopia is worn out like the Nature Theater of Oklahoma" (Mahler: A Musical Physiognomy, trans. Edmund Jephcott [Chicago: University of Chicago Press, 1992], pp. 148 and 150), a reference to the inconclusively redemptive final chapter of Kafka's novel Amerika (publ. 1927), the story of a banished European attempting to rescue himself in the magic of the American dream. Elsewhere I have argued that Mahler's musical processes have been far more influential on screen scoring practice than has generally been acknowledged (see "Plundering Cultural Archives and Transcending Diegetics: Mahler's Music as 'Overscore'," Music and the Moving Image 3 [2010]).

${ }^{25}$ Cook, A History of Narrative Film, p. 221.
}

at this time, ${ }^{26}$ it seems more certain that the forces of capitalism, spearheaded by spectacular postwar American growth, tamed and homogenized film spectatorship socioeconomically within cultures of yearning for the past and fear for the future, while also inevitably, but unwittingly, entrenching its other: the perception and jealous safeguarding of aestheticartistic differences and hierarchies. This apparent appeal to a social unity that paradoxically masks an irrevocable departure from that unity is intimated in Gerard Manley Hopkins's pointed inversion, and consequent subversion, of Wordsworth's very same sociopolitically conservative ideas in an otherwise trifling "triolet" written in the 1880s but not published until 1918:

"The child is father to the man."

How can he be? The words are wild.

Suck any sense from that who can:

"The child is father to the man."

No; what the poet did write ran,

"The man is father to the child."

"The child is father to the man!"

How can he be? The words are wild.

("The Child is Father to the Man.")

As may be inferred from Winkler, the cultural phenomenon of early film curiously combined two things: first, an extreme and potentially universalizing process of "high-art" music democratization and desacralization that was socially progressive and yet almost entirely defined by commercial concerns; and second, a process of demotic narrowing of this music's signifying potential that was creatively novel and undeniably effective in mass-media contexts but aesthetically prescriptive for its future consumption outside such contexts. With "Träumerei" this process developed from nineteenth-century precedents set in the work's increasingly bourgeois reception and consumption within salon and soirée contexts as well as piano pedagogy. With the help of the meaning accruing from these contexts and from the

\footnotetext{
${ }^{26}$ See Tom Gunning, "Early American Film," in The Oxford Guide to Film Studies, ed. John Hill and Pamela Church Gibson (Oxford: Oxford University Press, 1998), pp. 255-71; quotation p. 265.
} 
piece's title, such precedents quickly assumed the nature of a tradition within film scoring. Aesthetic abstraction of a rich childhood topic becomes the accompaniment of choice, whether for absurd purposes in slapstick cartoon (see below); or associated with the yearning for unreachable prelapsarian states in golden-era Hollywood melodrama and romance; or "maturing" into the symbol of convenience for an entrenched sentimentality in film of the last decade. Already uncertain distinctions between art for children and art "about" childhood recede as "Child" and "Man," or utopian vision, disillusionment, and nostalgia industry, disconnect and reconnect in antagonistic yet socially and aesthetically homogenizing ways, pushing claims of difference, hierarchy, and value judgment into the margins of a desperate conservatism itself restricted by its own brand of nostalgia for the mythical pristine.

Here we can see a curious amalgam of nineteenth- and early-twentieth-century trends in literary approaches to the child topic. Wordsworth's divine child of nature, symbol of hope and organic human integration, cedes to Matthew Arnold's "prematurely adult" child ("To a Gipsy Child," 1849) suggesting "adult despondency over a universe of fragmentation and pain" ${ }^{27}$ and thence to Dickens's exploration of deep childhood fears and guilt in Great Expectations (1860-61), Manley Hopkins's image of a child's fall from innocent grace into a decaying world in "Spring and Fall: to a young child" (1880), and, in Jude the Obscure (1895), Hardy's acts of negation through infanticide and child suicide, and the impossibility of Jude's desperate resistance to maturity: "If he only could prevent himself from growing up! He did not want to be a man." 28

Virginia Woolf's famous dictum from the postwar perspective of 1923, "On or about December 1910 human character changed," 29 has been interpreted in different ways: as a cultural

\footnotetext{
${ }^{27}$ U. C. Knoepflmacher, "Mutations of the Wordsworthian Child of Nature," in Nature and the Victorian Imagination, ed. U. C. Knoepflmacher and G. B. Tennyson (Berkeley: University of California Press, 1977), pp. 391-425; quotation p. 396.

${ }^{28}$ Cited in Knoepflmacher, "Mutations," p. 425.

${ }^{29}$ From the essay "Mr Bennett and Mrs Brown," 1923, Collected Essays, vol. 3 (London: Hogarth Press, 1966).
}

elitist's recognition of the rise of high-art modernist sensibilities in the wake of the reception of Chekov, Dostoyevsky, Wells, Butler, Freud's clinical assault on childhood innocence, and, with hindsight, the coming of D. H. Lawrence and Joyce; and as an indication of the wider sociopolitical change brought about by the end of the Victorian and Edwardian eras (Edward VII had died in May 1910). It should be remembered that this was also the time of the cult of J. M. Barrie, forged by Sentimental Tommy and Margaret Ogilvy (both 1896) and consummated in Peter Pan (1904, novelized in 1911), a work that onstage and in print captured the imagination of a newly emerging mass entertainment and literature marketplace and its taste for what Woolf might have considered a regressive form of emotional escape. Early commentators on Barrie observed its lure: "hundreds and thousands of [adults] at all kinds of extraordinary ages, fell right into his open trap. ... They couldn't get away from it. And they, too, suddenly, hated being grown up"; when the play was performed "all the audience are children." 30

If the nineteenth century can justly be called the "century of the child," a time when "childhood was first recognized as a distinct and essential phase of human life," ${ }^{\prime 31}$ then it is not surprising that, as Isabel Eicker has observed, the century saw a flourishing of child-inspired or child-oriented piano repertoire, among which Schumann's Kinderszenen, Album für die Jugend, and Drei Klaviersonaten für die Jugend played a prominent part in the search to reconnect with a mythical purity of youth. The coveted ideal of childhood's "capacity for fantasy" appeared to be a driving force for Schumann and others and invites us to consider its relationship with the composer's broader aesthetic development and with the issue under discussion here.

\footnotetext{
${ }^{30}$ Denis Mackail, The Story of I. M. B. (Sir James Barrie, Bart., O.M.) (London: Peter Davies, 1941); Thomas Moult Barrie (London: Cape, 1928), both cited in Peter Coveney, Poor Monkey: The Child in Literature (London: Rockliff, 1957), p. 201.

${ }^{31}$ Isabel Eicker, Kinderstücke: An Kinder adressierte und über das Thema der Kindheit komponierte Alben in der Klavierliteratur des 19. Jahrhunderts (Kassel: Gustav Bosse, $1995 \mid$, p. 20.
} 
Let us recall that the "Romantic and revolutionary," "socially utopian" aesthetics of Schumann was built on the promotion of a poetic music that stimulates imaginative responses, and on a "rejection of the culture of the prosaic" whereby society "trivialized and commercialized music by treating it as a commodity, an entertainment medium." 32 But this should be seen in the context of another of the composer's claims: that "philosophers can learn directly from music that, even through the outward appearance of trifling childlike levity, it is possible to say the most profound things about the world." 33 The question arises as to whether Schumann himself tapped into the cult of childhood as an act of nostalgia, as a means of returning, via Clara (whom he knew first as a child), to an Eden of lost innocence (or of reaching Clara via an Edenic path): "May you be my last, most exalted goal, Clara, angel of purity and innocence, lead me back to childhood," as he wrote in his diary two years before completing Kinderszenen. ${ }^{34}$ Or whether in embracing the childhood topic he was identifying with something already within him, the eternal infant as poetic muse: "In man there resides a tender genius that gently opens up for the eternal child gateways to new worlds and creations, and that, unnoticed and as if by chance, leads the youth in his first love to the blossoming spring with his beloved, uniting and revealing to each other their dreams." 35 There may well have been senses of both nostalgia and self-identity wrapped up together in Schumann's creative psyche and inhabiting reconstructed childhood worlds. Is it safe to assume, then, that in aesthetic terms he would likely have greeted the cinematic appropriation of the fertile dream work at the center of Kinderszenen with a mixture of horror and res-

\footnotetext{
${ }^{32}$ Ulrich Tadday, "Life and Literature, Poetry and Philosophy: Robert Schumann's Aesthetics of Music," in Perrey, The Cambridge Companion, pp. 38-47; quotation p. 45. ${ }^{33}$ Cited in Robert Schumann: Tagebücher: Bd. 1. 18271838, ed. Georg Eismann (Leipzig: Deutscher Verlag für Musik, VEB, 1971), p. 414

${ }^{34}$ Cited in Georges Starobinski, "Les Kinderszenen op. 15 de Schumann: Composantes Littéraires et Biographiques d'une Genèse," Revue de Musicologie 88/2 (2002), 361-88; quotation p. 384.

${ }^{35}$ Cited in Eismann, Robert Schumann, p. 105.
}

ignation? After all, not only is it called into commercial service for the sake of entertainment, but also through an apparent depthless realism and confining of semantic models its industrialized reprocessing seems to elide the poetic undecidedness and rhetorical questioning so dear to his aesthetic outlook. ${ }^{36}$ Schumann took Rellstab's critique that the collection did not conform to established norms of illustrative children's music to be a complete misconception: the "very considerable meticulousness of the enterprise" standing in "opposition to the title." "Thus we can take the title 'Kinderscenen' merely as an indication of the composer's flight of fancy; but his work refers to children as little as a Pastorale would be written for shepherds. ${ }^{\prime 37}$ It is also well known that Schumann was critical of the kind of prescriptive and explicit program attached to a work such as Berlioz's Symphonie fantastique for "having his thoughts so rudely directed." $\mathrm{He}$ acknowledged that "chance influences and impressions from outside" can play important functions for composers in the act of creation, and that such ideas can enhance the exactitude of the listening experience. But the search for what we might now call music's semiotic "object" or "signified" was something that, for Schumann, can be taken too far by listeners: "One is certainly mistaken if one believes that composers take up pen and paper just with the paltry idea of expressing, or describing, or painting this or that." In this regard, and with spe-

\footnotetext{
${ }^{36}$ See John Daverio, Nineteenth-Century Music and the German Romantic Ideology (New York: Schirmer Books, 1993), p. 87; Leon Botstein, "History, Rhetoric, and the Self: Robert Schumann and Music Making in GermanSpeaking Europe, 1800-1860," in Schumann and His World, ed. R. Larry Todd (Princeton: Princeton University Press, 1994), pp. 3-46, esp. pp. 29-30; and Laura Tunbridge, "Piano Works II: Afterimages," in Perrey, The Cambridge Companion, pp. 86-101, esp. pp. 93-94.

37"Die so gar große Richtigkeit der ganzen Unternehmung, und der Widerspruch, in dem dieselbe mit dem Titel steht." "So können wir denn den Titel 'Kinderscenen' nur für einen halten, der den Phantasiegang des Componisten bezeichnen sollte., seine Schöpfung aber so wenig den Kindern zuwieß, wie ein Pastorale für Hirten geschrieben ist" (Iris im Gebiete der Tonkunst 10/32 [Berlin, 1839], 126-27, cited in Bernhard R. Appel, "Ein productives Mißverständnis: Robert Schumanns 'Kinderszenen' op. 15 in der Kritik Ludwig Rellstabs," Die Musikforschung 40 [1987], 109-15; quotation 109 and 110 [my trans.]).
} 
cial significance for the cinematic appropriation of music under discussion here, for good or ill, Schumann admitted: "Once the eye has been led to a given point, the ear no longer judges independently." 38 If we are to believe Schumann, the compositional process of Kinderszenen bore out his subtle aesthetic outlook in that, on the one hand, he did not crassly place children before him and "then search for tones accordingly," asserting conversely that "the titles originated afterwards" 39 (and in general titles for Schumann were "nothing but delicate directions for execution and interpretation" 40 ); but on the other hand, he conceded that "while composing, some children's heads were hovering around me." 41

Even before composing Kinderszenen he recognized the subtle element of fantasy playacting engaged in by certain music: "[which,] pretending to be a playing child with a brimfull heart that it is almost ashamed to reveal to the wise and learned ... mischievously hides behind its tinkling musical figures ... with wonderful sound-meanings which knock at every human heart with the quiet question 'Do you understand me?', but are by no means understood by everyone." 42 The lurking elitism of this comment whereby only the privileged few are admitted into the secret world of illumination might seem a strange bedfellow for childlike games. This Socratic dialogue intimates a tension between the private and the public that would later lie at the heart of the experience of

\footnotetext{
${ }^{38}$ This and previous quotations from Schumann, "A Symphony by Berlioz," trans. Edward Cone, in Hector Berlioz, Fantastic Symphony: An Authoritative Score: Historical Background, Analysis, Views and Comments, ed. Edward Cone (New York: Norton, 1971), pp. 220-48; quotations pp. 246-48. See also Fred Everett Maus, "Intersubjectivity and Analysis: Schumann's Essay on the Fantastic Symphony," in Music Theory in the Age of Romanticism, ed. Ian Bent (Cambridge: Cambridge University Press, 1996), pp. 125-37, in which Maus says of Schumann's comments: "This means that the program is irritating, but not that its content is false," p. 132.

${ }^{39}$ Cited in Appel, "Ein productives Mißverständnis," p. 113 (my trans.).

${ }^{40}$ Cited in Thomas Alan Brown, The Aesthetics of Robert Schumann (New York: Philosophical Library, 1968), p. 178.

${ }^{41}$ Cited in Appel, "Ein productives Mißverständnis," p. 113 (my trans.).

${ }^{42}$ Cited in Brown, The Aesthetics of Robert Schumann, p. 167.
}

film consumption, ${ }^{43}$ where there is potentially less concern for individual subtlety and enigma, however much the darkened atmosphere might give the impression of the opposite, as situations and meanings are necessarily presented and received communally. In such a context everyone is required to understand, and so it would appear that the secret answer whose deferral, elusiveness, or abstruseness is the very meaning of Schumannian Romanticism has rather to be driven home in many areas of mainstream screen culture. At the behest of a twentieth- and twenty-first-century economic imperative the searching artistic profundity of "childlike levity" is traded for the certainty of information commodities in the belief that the "tinkling musical figures" are all there is. Again, in a bid to preserve putative origins, it is tempting to lapse into a reassuring aristocracy of aesthetic assumptions, and to conclude that rich connotation may thus become narrow denotation, dialogic interpretation may become monologic data-retrieval, and music may become fossilized and expedient lingua franca. Probing the nature of Schumann's practical creative life and the screen appropriation of his music may provide some insight into the validity of this apparent polarity between a "richer" nineteenth-century Romantic poetics and a "poorer" twentieth-century mass-media culture.

First, as some have noted, like so many of his early-nineteenth-century, post-patronage-era contemporaries, Schumann was compelled to confront the bourgeois marketplace with all its inherent restrictions and opportunities, particularly when as a young composer he felt the need to demonstrate his credentials as Clara's future husband, and even more intensely than most through his promotional activities as editor of the Neue Zeitschrift für Musik. Anthony Newcomb has suggested that Kinderszenen offered the first, perhaps unintentional, example

\footnotetext{
${ }^{43} \mathrm{Home}$ consumption of cinematic product, a result of the post-1960s television and video age, admittedly lends a different perspective to the public-private distinction, but the prevailing economics of big-screen production still determine that, apart from certain "straight-to-video/DVD" fare, the primary arena of reception is communal. Preview screenings to large groups of people demonstrate a perceived need for consensual approval and understanding.
} 
of Schumann's ability-as a musician "extremely attentive and sensitive to published reactions to his work" and faced with Wieck's patriarchal pressure-to produce marketable, accessible music. Opus 15 was certainly among his best-selling collections, reaching sales of between 300 and 350 copies in the first six months after its publication by Breitkopf and Härtel. More significantly, it bore the hallmarks of the peculiarly German phenomenon of approachable, middle-class Hausmusik, which was on the point of enjoying a revival and cultural consolidation in the Vormärz years, and indeed continued to flourish after 1848, the period in which "Träumerei" began its steady march toward independent fame and assumption into general consciousness. This must be seen in the context of Clara's populist plea to Schumann in 1839 for "something . . . easily understandable . . . without titles . . . something written for an audience," and Schumann's response to her similar request in the previous year: "Clara. . . . You write that I should write quartets-but 'please good and clear'-that sounds indeed like something from the mouth of a Dresden Fräulein." 44 Thus Kinderszenen might seem to have been in part the result of artistic compromise and personal acquiescence to the influence of a practical performing artist working in the real world of public music consumption. As early as 1840 , for example, Schumann would refer to the pieces condescendingly (though not without some justification) as "mere bagatelles" in comparison with other, more substantial works. ${ }^{45}$ And in a letter to Carl Koßmaly in 1843, he all but admitted the concessions he had had to make to professional and family demands: "when one has a wife and children it is completely different-one certainly must think of the future, one also wants to see the fruits of one's labor, not the artistic but the prosaic, which belong to life and only

\footnotetext{
${ }^{44}$ Newcomb, "Schumann and the Marketplace: From Butterflies to Hausmusik," in R. Larry Todd, Nineteenth-Century Piano Music (New York: Routledge, 2004), pp. 258315; quotations pp. 265 and 266.

${ }^{45}$ Cited in Nancy B. Reich, Clara Schumann: The Artist and the Woman (London: Victor Gollancz, 1985), p. 109.
}

increase one's reputation." 46 Indeed, the degree to which the collection, and especially "Träumerei," successfully addressed the demands of the comfortable, intimate, familialcollective Hausmusik tradition, and the more challenging, communal social-collective concert tradition, as well as the philosophical demands of early Romantic music aesthetics, is something that screen appropriations compel us to reconsider in their recontextualizing and reimagining of the work's signifying range and function.

Anomalies emerge from this process of musical domestication engendered by Clara who, as an internationally renowned concert pianist, was not only already well versed in matters of public musical commerce but also occupied a traditionally masculine social space in the partnership. These circumstances may well have magnified for Schumann the difficulty, even futility, of trying either to maintain (as a man) or fully to escape (as a Romantic artist) the kind of petit-bourgeois familial arrangements, taste, and outlook inherited from his parents. Although, as Michael Steinberg notes, such a legacy risked "transform[ing] the home into the kleinbürgerlich nightmare from which Schumann could never free himself," 47 the degree to which this shift overlapped with the kind of feminization of the composer's creative personae suggested by Lawrence Kramer (via Nietzsche and Schumann's own comments from 1838) is open to debate. ${ }^{48}$ The central paradox here is that on the one hand this seemingly inescapable "intimacy and privacy"-for Steinberg ostensibly "split off from the public and rhetorical" - nevertheless become markers of wider Biedermeier fashion, of what he calls "bourgeois essentialism and rigidity," 49 and hence another part of its climate of collective escapism to which Clara, as virtuoso performer,

\footnotetext{
${ }^{46}$ Cited in David Ferris, "Public Performance and Private Understanding: Clara Wieck's Concerts in Berlin," Journal of the American Musicological Society 56/2 (2003), 351408; quotation 405.

${ }^{47}$ Michael Steinberg, "Schumann's Homelessness," in Todd, Schumann and His World, pp. 47-79; quotation p. 76.

${ }^{48}$ See Lawrence Kramer, "Rethinking Schumann's Carnaval: Identity, Meaning, and the Social Order," in Kramer, Musical Meaning: Toward a Critical History (Berkeley: University of California Press, 2002), pp. 100-32. 49"'Schumann's Homelessness," p. 54.
} 
was a prime contributor. On the other hand, Schumann's earlier crusade against Philistinism was couched in a belief that his music, ideas, and contributions to culture would inaugurate a new generation of cognoscenti that would act as a buttress against the degradation of art and artistic standards: "An advance of our art would occur first with an advance of artists towards an aristocracy of the mind, the statutes of which do not merely demand knowledge of the bare mechanics ... in order to bring about an epoch of a higher level of general musical culture." 50

History has shown that the first of these paths of transformation continued unabated since its first instantiation in Biedermeier culture. It occurred initially through the widespread assumption of an uprooted "Träumerei," and arrangements thereof, into public consciousness in post-Biedermeier German (and wider European) society such that, according to views stretching across the last half-century, the work has "achieved universal recognition," "assumed an independent existence," and "attained household status." 51 This path then intensified and diversified in the more rigidly bourgeois and increasingly commercial patterns of consumption lying at the heart of the cinematic experience in the early twentieth century (and later)a process that was part of a larger shift in tension between notions of high and low and communal vs. personal culture that Lawrence Levine charts in turn-of-the-century America. ${ }^{52}$ Resembling Schumann's adult perspective on childhood topics in Kinderszenen, this consumption combined childlike wonderment, "a vacillation between belief and incredulity" 53 at the novelty

${ }^{50}$ Cited in Brown, The Aesthetics of Robert Schumann, $\mathrm{p}$. 30 .

${ }^{51}$ Kathleen Dale, Nineteenth-Century Piano Music: A Handbook for Pianists (London: Oxford University Press, 1954; rpt. New York: Da Capo Press, 1972), p. 237; Alan Walker, Schumann (London: Faber \& Faber, 1976), p. 48; Erika Reiman, Schumann's Piano Cycles and the Novels of Jean Paul (Rochester: University of Rochester Press, 2004), p. 152

${ }^{52}$ Lawrence Levine, Highbrow/Lowbrow: The Emergence of Cultural Hierarchy in America (Cambridge, Mass.: Harvard University Press, 1988).

${ }^{53}$ Tom Gunning, "An Aesthetic of Astonishment: Early Film and the (In)credulous Spectator," in Film Theory and Criticism, ed. Leo Braudy and Marshall Cohen (5th edn. New York: Oxford University Press, 1999), pp. 818-32; quotation p. 823. and power of the medium, with unchildlike awareness of the signifying properties of its audio-visual content. As the spectacular "cinema of attractions" ${ }^{\prime 54}$ gave way to narrative constructions, as silent film turned to sound film, and as music's function within these multimedia complexes shifted between varied layers of aesthetic dominance and subservience, practicality and semantic resonance, so in their responses audiences veered between surrendering to purely sensory experience (as film music "recaptures the pleasure of the [infant's] sonorous envelope" and "primordial sonic space" and culturally identifying with music "as a signifying structure, and . . . as a form of representation and emotional expression," sometimes "foregrounded in order to further the .. . sense of structural unity or narrative coherence ${ }^{\prime \prime 56}$ or even to suggest dimensions of meaning supplementary or contrary to those of a film's other domains. This widespread historical model of cinematic development is itself predicated on a Freudian metaphor that in turn owes much to Romantic theorizing about the importance of childhood: "in Gunning's suggestion that the cinema of attractions somehow survives (albeit in a suppressed way) in the primarily narrative-driven classical cinema, we can recognize the widely shared belief that childhood traits continue to exist inside every adult." ${ }^{57}$ Keeping such developments in mind, we may now turn to the ways in which "Träumerei" has specifically figured and functioned in these conflicting spectacle- and storyoriented contexts of film's history.

\footnotetext{
${ }^{54}$ Gunning's term. See his "The Cinema of Attractions: Early Film, Its Spectator, and the Avant-garde," Wide Angle 8 (1986), 63-70; "An Aesthetic of Astonishment"; and "Early American Film."

${ }^{55}$ Claudia Gorbman, "Film Music" in The Oxford Guide to Film Studies, ed. John Hill and Pamela Church Gibson (Oxford: Oxford University Press, 1998), pp. 43-50; quotation p. 47.

${ }^{56} \mathrm{Jeff}$ Smith, "Unheard Melodies? A Critique of Psychoanalytic Theories of Film Music," in Post-Theory: Reconstructing Film Studies, ed. David Bordwell and Noël Carroll (Madison: University of Wisconsin Press, 1996), pp. 23047; quotations pp. 245 and 236.

${ }^{57}$ Dimitris Eleftheriotis, "Early Cinema as Child: Historical Metaphor and European Cinephilia in Lumière $\oplus$ Company," Screen 46/3 (2005), 315-28; quotation p. 317.
} 
The “Träumerei" Protocol in SOUND Cinema

Animation. Resistance to the demotic trends of popular cultural appropriation remained strong in some quarters. As late as 1927 the composer and regular Musical Times contributor Alexander Brent-Smith, clinging to fading concepts of authorial presence, found it inconceivable for a work such as "Träumerei" to be placed successfully in anything other than a serious context: "Try to imagine Schumann using his 'Träumerei' or Schubert his 'Litany' for the theme of the story of the sleeping princess and the brawling knight! It is unthinkable. Those composers knew that their music was beautiful, and they prized it too highly to spoil it with humour." 58 Despite this, it is no accident that in the first wave of its appropriation by sound cinema (1932-53) fourteen of the nineteen instances I have been able to identify are from cartoons-the archetypal entertainment model designed for adult-as-child viewing, plying caricature and absurdity in its packaging of sentiment (see Table 1).59 It should be noted that before the advent of television adults formed an essential part of the target demographic of animated film and have come to do so again only in recent years. ${ }^{60}$ Thus the use of culturally entrenched repertoire such as "Träumerei" fulfilled a practical as well as a putative aesthetic function in encouraging audiences to take pleasure in the recognition of the familiar-a practice that certainly stretched back to

\footnotetext{
${ }^{58}$ Alexander Brent-Smith, "Humour and Music," Musical Times 68/1007 (1 Jan. 1927), 20-23; quotation 22.

${ }^{59}$ Resources for this part of my research have centered on the Internet Movie Database, various Schumann-, or "Träumerei"-related web searches, credit listings from Sight e) Sound and film guides, the library of the BFI, London, and communication from other individuals. Schumann's music has been employed, either diegetically or nondiegetically, in at least fifty narrative feature films and short films. Over half of these instances involve "Träumerei," making it by far the most commonly used work of the composer within the cinematic repertoire. ${ }^{60}$ See Kristin Thompson, "Implications of the Cel Animation Technique," in The Cinematic Apparatus, ed. Teresa de Lauretis and Stephen Heath (New York: St. Martin's Press, 1980), pp. 110-11; and Daniel Goldmark, Tunes for 'Toons: Music and the Hollywood Cartoon (Berkeley: University of California Press, 2005), p. 3.
}

live piano accompaniment in the $1910 s^{61}$ and possibly to even earlier stage practices.

The ironies of cartoon repertoire in its 1930s50 s "golden age" are manifold. First, the production of cartoons as unashamedly popular massentertainment nevertheless depended for its impact on levels of cultural and musical literacy that cut across prevailing high-low/popular-classical divisions and, in typically rapidfire symbolic or iconic composite scores, tapped into the "collective unconscious which ... unknowingly makes the connection between the few bars of the motif ... and the plot development or idea put across on screen." 62 Second, as audiences quickly became more adept at identifying, or identifying with, musical numbers, and as composers and arrangers such as Carl Stalling became cleverer at compiling mosaic scores, efficiency dictated both that ever smaller excerpts were all that were needed to produce the desired effect, and that "the canon of classical film music ... was reduced by cartoons to an even more limited set of works." Third, despite this reliance on knowledge of classical repertoire, there was, as Daniel Goldmark has observed of Hollywood cartoons of this era-a repertoire "never seen by the public as anything but pop culture" 63 -a marked leaning (implicit and often explicit) toward the comedic undermining of "high-art" pretensions. This multiform process of narrowing the focus of what constituted classical "high-art" music in the eyes of the cinemagoing public, of paring down content in forms of extreme synecdochical communication reminiscent of the short cuts of everyday speech, and of subverting elitist aesthetic hierarchies, was but one part of the response to the nineteenthcentury Anglo-American "sacralization of culture" and of the subsequent renegotiations of cultural space identified by Levine. ${ }^{64}$

\footnotetext{
${ }^{61}$ See Altman, "Early Film Themes: Roxy, Adorno and the Problem of Cultural Capital," in Beyond the Soundtrack: Representing Music in Cinema, ed. Daniel Goldmark, Lawrence Kramer, and Richard Leppert (Berkeley: University of California Press, 2007), pp. 205-24, esp. p. 217.

${ }^{62}$ Will Friedwald, "Sublime Perversity: The Music of Carl Stalling," in The Cartoon Music Book, ed. Daniel Goldmark and Yuval Taylor (Chicago: A Cappella Books, 2002), pp. 137-40; quotation p. 139.

${ }^{63}$ Goldmark, Tunes for 'Toons, pp. 108, 130.

${ }^{64} \mathrm{See}$ n. 52 for citation.
} 
Table 1

Sound films employing Schumann's "Träumerei"

\begin{tabular}{|c|c|c|c|c|}
\hline $\begin{array}{c}\text { Title } \\
\text { ( }{ }^{\star} \text { INDICATES AN } \\
\text { ANIMATED FILM) }\end{array}$ & Director & Studio & $\begin{array}{c}\text { COMPOSER/ } \\
\text { MUSICAL DIRECTOR }\end{array}$ & $\begin{array}{c}\text { USE OF "TräUMEREI" } \\
\text { (MEASURES } \\
\text { AND DURATION) }\end{array}$ \\
\hline
\end{tabular}

$\begin{array}{lcll}\begin{array}{l}\text { Fiddling Around } \\ \text { (aka Just Mickey) }\end{array} & \text { Walt Disney } & \begin{array}{l}\text { Walt Disney } \\ \text { Productions/ } \\ \text { (1930)* }\end{array} & \begin{array}{l}\text { Unknown } \\ \text { (original music }\end{array} \\ \begin{array}{l}\text { Three's a Crowd } \\ (1932)^{\star}\end{array} & \text { Rudolf Ising } & \begin{array}{l}\text { Leon Schlesinger } \\ \text { Studios }\end{array} & \text { Frank Marsales } \\ \text { Rhythm in the Bow } & \text { Ben Hardaway } & \begin{array}{l}\text { Leon Schlesinger } \\ \text { Studios }\end{array} & \text { Norman Spencer } \\ (1934)^{\star} & & & \end{array}$

The Hot Cha Melody (1935)*

\section{$M$} \&

Ben Harrison

Break of Hearts (1935)

We Went to

College (1936)

I Love to Singa $(1936)^{\star}$

Porky's Poultry Plant $(1936)^{\star}$

Porky's Romance (1937)*

Daffy Duck $\Theta$ Egghead (1938) *
Philip Moeller RKO Radio Pictures

Joseph Santley MGM

Tex Avery

Leon Schlesinger Studios

Frank Tashlin

Leon Schlesinger Studios

Frank Tashli

Leon Schlesinger Studios

Tex Avery

Leon Sc Studios mm. 1-8; 17-24

1 min. 42 secs.

mm. $1-8 ; 17-23^{2} ; 24$

44 secs.

mm. $1-5^{2} ; 2^{4}-3^{4}$

(whistled)

28 secs.

mm. 1-8 ${ }^{2}$; mm. 1-4, $1-3^{3}, 24^{3-4}, 1-3^{3}, 24^{3-4}$ $2^{3.5}-3^{3}, 24^{3-4} ; \mathrm{mm} .1-3^{3}$, $24^{3-4}, 1-4,1-3^{3}, 24^{3-4}$, $1-3^{3}, 24^{3-4}, 1-4,1-3^{3}$, $24^{3-4}, 1-3^{3}, 24^{3-4}, 1-4$, $1-3^{3}, 24^{3-4}, 1^{2}-3^{3}, 24^{3-4}$ (last note extended by 4 beats) 25 secs. of original on piano with strings; 37 secs. of "Hotcha Melody" on piano (with strings); $1 \mathrm{~min} .46$ secs. of "Hotcha Melody" on radio

Complete (including repeat of mm. 1-8; diegetic on piano mm. $1-4^{2}$; after short break taken up nondiegetically by ensemble)

2 min. 48.5 secs unknown

mm. $1-2^{3}$

11 secs.

mm. 1-42 (played in $2 / 4$, omitting beats $1^{2}$ and $2^{3}$ )

15.5 secs.

mm. 1-2

7.5 secs.

$\mathrm{mm} .1-3^{2.5}$

11 secs. 


\begin{tabular}{|c|c|c|c|c|}
\hline $\begin{array}{c}\text { TITLE } \\
\left({ }^{\star} \text { INDICATES AN }\right. \\
\text { ANIMATED FILM) }\end{array}$ & DIRECTOR & STUDIO & $\begin{array}{c}\text { COMPOSER/ } \\
\text { MUSICAL DIRECTOR }\end{array}$ & $\begin{array}{c}\text { USE OF "TRÄUMEREI" } \\
\text { (MEASURES } \\
\text { AND DURATION) }\end{array}$ \\
\hline
\end{tabular}

\begin{tabular}{|c|c|c|c|}
\hline $\begin{array}{l}\text { A Slight Case of } \\
\text { Murder (1938) }\end{array}$ & Lloyd Bacon & Warner Bros. & $\begin{array}{l}\text { Adolph Deutsch, } \\
\text { Howard Jackson \& } \\
\text { Heinz Roemheld }\end{array}$ \\
\hline
\end{tabular}

Americaner Shadchen (1940)

Tom Thumb in

Trouble (1940)*

Malibu Beach Party Fritz Freleng (1940)*

Duck Soup to Nuts Fritz Freleng $(1944)^{\star}$

\begin{tabular}{|c|c|}
\hline $\begin{array}{l}\text { Hare Ribbin' } \\
(1944)^{\star}\end{array}$ & $\begin{array}{l}\text { Robert } \\
\text { Clampett }\end{array}$ \\
\hline Träumerei (1944) & Harald Brau \\
\hline
\end{tabular}

The Old Grey Hare $(1944)^{\star}$

Robert

Song of Love (1947)

Clampett

Clarence

Brown

$\begin{array}{ll}\text { Big City (1948) } & \text { Norman } \\ & \text { Taurog }\end{array}$

Hare Trimmed (1953)*

Ludwig (1972)
Madame Sousatzka
(1988)

Fritz Freleng

Luchino

Visconti

John

Schlesinger
Fame Films Inc.

Sam Morgenstern

Carl Stalling

\section{Leon Sc Studios}

Leon Schlesinger Carl Stalling Studios

Warner Bros.

Warner Bros

UFA

Warner Bros.

MGM

MGM

MGM

Warner Bros.

Mega Film

Cineplex-Odeon Films mm. 1-3 3 , 23 $3^{4}-24^{1}$

(last note changed from $\mathrm{D}$ to $\mathrm{F}$ and extended in length) 21 secs.

unknown

mm. 1-44 (final C of measure omitted) 20 secs.

mm. 1-14 3 (no repeat of mm. 1-8); short pause then mm. 20-24 1 min., 11 secs.

mm. 1-123 (no repeat of mm. 1-8) 60 secs.

mm. 1-7 38 secs.

m. $1^{\text {upbeat- } 1}$ used several times in opening credits mm. 1-8 (no repeat); $9-12^{3} ; 16^{4}-24^{2}$

mm. 1-4

mm. 1-4; 214-24

2 min. 35 secs.

mm. 1-8, 11-2

42 secs.

mm. 1-24 (no repeat of mm. 1-8)

1 min. 58 secs.

mm. 17-24

50 secs.

mm. $1-3^{1}$

9 secs.

$\mathrm{mm}$. 1-11 (with repeat of mm. 1-8) 2 min. 7 secs.

mm. 1-12 2.5 (no repeat of mm. 1-8)

57 secs. 


\begin{tabular}{|c|c|c|c|c|}
\hline $\begin{array}{c}\text { TitLE } \\
\left({ }^{\star} \text { INDICATES AN }\right. \\
\text { ANIMATED FILM })\end{array}$ & Director & STUdio & $\begin{array}{c}\text { COMPOSER/ } \\
\text { MUSICAL DIRECTOR }\end{array}$ & $\begin{array}{c}\text { USE OF "TRÄUMEREI" } \\
\text { (MEASURES } \\
\text { AND DURATION) }\end{array}$ \\
\hline $\begin{array}{l}\text { The Loss of Sexual } \\
\text { Innocence (1999) }\end{array}$ & Mike Figgis & $\begin{array}{l}\text { Newmarket } \\
\text { Capital Group }\end{array}$ & Mike Figgis & $\begin{array}{l}\text { Complete (including } \\
\text { repeat of } \mathrm{mm} .1-8 \text { ) } \\
2 \text { min. } 40.5 \text { secs. }\end{array}$ \\
\hline $\begin{array}{l}\text { Tea with Mussolini } \\
\text { (1999) }\end{array}$ & $\begin{array}{l}\text { Franco } \\
\text { Zeffirelli }\end{array}$ & Cattleya & $\begin{array}{l}\text { Stefano Arnaldi \& } \\
\text { Alessio Vlad }\end{array}$ & $\begin{array}{l}\text { mm. } 1-8 \text { (melody only) } \\
39 \text { secs. }\end{array}$ \\
\hline Crush (2001) & John McKay & Film Council & $\begin{array}{l}\text { Kevin Sargent \& } \\
\text { Dana Sano }\end{array}$ & $\begin{array}{l}\mathrm{mm} .1^{1} \text {; short break, } \\
\text { then } \mathrm{mm} .1-5^{1} \\
20 \text { secs. }\end{array}$ \\
\hline Wasabi (2001) & $\begin{array}{l}\text { Gérard } \\
\text { Krawczyk }\end{array}$ & Europa Corp. & $\begin{array}{l}\text { Julien Schultheis \& } \\
\text { Eric Serra }\end{array}$ & $\begin{array}{l}\text { mm. } 1-4,21-24 \\
49 \text { secs. }\end{array}$ \\
\hline Swing (2003) & Martin Guigui & $\begin{array}{l}\text { Razor Digital } \\
\text { Entertainment }\end{array}$ & Gennaro Cannelora & $\begin{array}{l}\text { Jazz arrangement } \\
\text { lasting } 57 \text { secs. } \\
\text { Only mm. } 1-8 \text { are } \\
\text { recognizable (these, } \\
\text { with introduction, } \\
\text { last } 33 \text { secs.) }\end{array}$ \\
\hline $\begin{array}{l}\text { Beyond Borders } \\
\text { (2003) }\end{array}$ & $\begin{array}{l}\text { Martin } \\
\text { Campbell }\end{array}$ & Mandalay Pictures & James Horner & $\begin{array}{l}\text { mm. } 1-8,21-24 \\
1 \text { min. } 18 \text { secs. } \\
\text { mm. } 2^{4-8}, 21-23^{3} \\
\text { (pause on last note) } \\
58 \text { secs. } \\
\text { mm. } 8^{3-4}, 21-24 \\
32 \text { secs. } \\
\text { mm. } 1-4,21-24 \\
50 \text { secs. }\end{array}$ \\
\hline Bizan (2007) & Isshin Inudô & $\begin{array}{l}\text { Bizan Seisaku } \\
\text { linkai, Fuji } \\
\text { Television Network } \\
\text { et al. }\end{array}$ & Michiru Ohshima & unknown \\
\hline
\end{tabular}

Sometimes embedded in highly skillful and inventive compilation scores and at other times forming a more extended section of "underscore," "Träumerei" excerpts lasting between 7.5 secs. and 1 min. 48 secs. generally fulfill three differing levels of increasingly prominent and complex aesthetic and semantic function, which I term "reflective," "active," and "selfreferential" - though these functions are somewhat permeable-in the context of two interrelated emotional situations as identified below. "Reflective" usage tends to be aesthetically and semantically predictable in that a fragment or portion of the piece is employed for the purposes of mirroring the scene's instantaneous or short-lived emotional conditions. Such usage recruits the music's immediate and unequivocal association with either romantic attachment or death/loss-related pathos /genuine or mock, depending on the general tenor of the story), occasionally mediated through the topos of the dream. For example, in Porky's Poultry Plant (1936) the music appears when a weeping Porky is surveying a wall of posters bearing the names of (presumably dead) chickens that had been kidnapped by a predatory hawk. In Porky's 
Romance (1937) a suicidal and concussed Porky dreams that he is marrying his beloved, their vows accompanied by an excerpt on violins and harp. Similarly a cross-dressing Bugs Bunny takes Yosemite Sam to the altar in Hare Trimmed (1953) and a "diegetic" version is heard on the organ as they begin their vows. ${ }^{65}$ After several failed attempts to shoot Daffy (repeatedly accompanied by the William Tell Overture fanfare at ever-rising pitches), Egghead in Daffy Duck and Egghead (1938) is dressed by the condescending duck in dark glasses with a "Blind" placard around his neck to an orchestral snippet of the piece. In Duck Soup to Nuts and Hare Ribbin' (both 1944) the music accompanies outbursts of false and genuine grief respectively as Daffy and Bugs are either on the point of being shot or thought to be dying. Outside of any comedic context, Tom Thumb in Trouble (1940) generates large degrees of pathos as Tom decides to go searching in the cold winter night for the bird that earlier that day had saved his life (but which Tom's father suspects of trying to kill his son). The pathetic note left on his pillow: "the bird is my friend, he saved me and I'm going to look for him" is accompanied by a solo-violin version full of portamenti. Thus a first-level semantics establishes itself in these examples around basic sentiments of sorrow and love, whether played "straight" or associated with ridicule. The extent to which such readings drew on Schumann's reputation as "suffering romantic hero" forged by a devoted Clara (always dressed in the black attire of widowhood in public ap-

\footnotetext{
${ }^{65}$ Although I have not conducted a comprehensive and systematic survey, it is worth noting that organ arrangements of "Träumerei" were included in Melodious Melodies Arranged for the Organ or Harmonium by John Owen (London: C. Jefferys, 1875) (see The Musical Times and Singing Class Circular 17/391 [1 Sept. 1875], 197); Selected Movements from the Works of the Great Masters for the American Organ or Harmonium, ed. J. S. Anderson (London: Bayley \& Ferguson, 1904) (see Musical Times 45/732 [1 Feb. 1904], 138); Ten Easy and Useful Transcriptions for Organ by Edward Shippen Barnes (New York: G. Schirmer, 1921), The Organist Recital Series (London: Gould \& Bolttler, 1928) (see Musical Times 69/1029 [1 Nov. 1928], 1046); and The Anthology of Organ Music (London: W. Paxton, 1930). Evidence also exists of "Träumerei" being performed as a recital item by various organists in early-twentieth-century America, in New Music Review and Church Music Review (1906), 278, 457, and 561, and (1912), 42.
}

pearances and performances during the posthumous decades) is open to debate.

The category of "active" usage presents a different level of aesthetically provocative scoring, in which the music intervenes to embody, drive, or affect the narrative and scenario rather than merely supplying emotional "corroboration." Fiddling Around (also known as Just Mickey, 1930) provides an early example of the comic deflation of high-art pretensions discussed above. It thematizes the very act of solo virtuoso performance by having Mickey Mouse give an onstage violin recital that is preceded by pratfalls and breaking strings and ends with the instrument snapping apart under the strain of the William Tell Overture, or Overture William To Hell, as it is introduced here. After an impossibly fast rendition of Brahms's Hungarian Dance No. 5, a spotlight is trained on Mickey, casting his shadow on the stage curtain behind and suggesting a more intimate and earnest setting for the next work, which is an extremely labored "Träumerei" played with ridiculously excessive portamenti. So forcefully emotive is the performance that, drawing on the same pathos topic, the cartoon soon has Mickey reduced to tears, griefstricken, moaning (on or near a sustained F), interrupting himself by having to blow his nose, and finally exiting the stage, unable to complete the work. The ensuing rapturous applause seems to respond as much to the artistic involvement, devotion, and resulting "justifiable" breakdown as it does to the expressive feeling of what is actually played-indeed the two are perhaps inseparable here. What seems to be lampooned is the overly affected manner of classical artistic self-sacrifice to the demands of "great art." Schumann's piece, short enough for a good proportion of it to fit into the cartoon's timescale, is evidently held to be both an ideal vehicle, undoubtedly because of its real-world historical susceptibility to over-sentimentalized performance styles, and a universal emblem of cultural hierarchies on account of its widespread familiarity to audiences.

Three's a Crowd (1932) offers an interesting mixture of highbrow and lowbrow cultural allusions. Here a dance-orchestra version of the piece with additional countermelodies and links between phrases, is rhythmically regularized 
(at a tempo not far off from Schumann's recommended quarter note $=100$ ) to fit sonically with a ticking and chiming clock and visually with the rocking-chair movement and halting step of an old man who, at the beginning of the cartoon, gets up from his chair, extinguishes a candle and retires to bed, thus setting off a chain of fantasy events (book characters coming to life) that by implication are the products of his dream, since he has just been reading Alice in Wonderland. A roll call of popular literary classics appears along with their characters and others from legend and history: Robinson Crusoe, Rip Van Winkle, The Three Musketeers, an unidentified volume by Omar Khayam (most likely The Rubáiyát), Uncle Tom's Cabin, Tarzan, and the figure of Robin Hood, together with a biography of Napoleon, Chic Sale's 1929 The Specialist, ${ }^{66}$ Shakespeare's Henry VIII and Antony and Cleopatra, and Dr. Jekyll and Mr. Hyde. Characters sing and dance to the title song (by Harry Warren, Al Dubin and Irving Kahal from the 1932 film Tip Tap Toe), mock-Arabian music, Stephen Foster's "Old Black Joe" and "Got the South in My Soul" (Ned Washington, Victor Young, and Lee Wiley, 1932), and process to Chopin's "Funeral March" as the evil Mr. Hyde, who has attempted to kidnap Alice, is dumped into the wastepaper bin. ${ }^{67}$ All takes place in a gleeful, childlike atmosphere whose apparent inclusivity could be taken as a gentle throwback to a nineteenthcentury America in which, as Levine observes, even the works of Shakespeare enjoyed a greater degree of "simultaneously high cultural status and mass popularity." ${ }^{68}$ Or it could be that this film, along with many others of its kind made in the burgeoning era of true mass entertainment, finally debunks the utopian myth of cultural uniformity and tries to rescue notions of artistic value for the determinedly accessible and popular.

In Rhythm in the Bow (1934) the music is

\footnotetext{
${ }^{66}$ The comic story of the builder Lem Putt who specialized in building outdoor "privvies." Chic Sale (1885-1936) was a well-known stage comedian and film actor.

${ }^{67}$ Rouben Mamoulian's Dr. Jekyll and Mr. Hyde, starring Fredric March, had been released in 1931. Interestingly it featured a diegetic performance of Schumann's "Aufschwung" from Fantasiestücke, op. 12.

${ }^{68} \mathrm{Highbrow} /$ Lowbrow, p. 233.
}

employed in a surrounding popular music context containing Cliff Hess's title song, Harry Warren's "Shuffle off to Buffalo," "Kingdom Coming" (also known as "The Year of Jubilo") by Henry Clay Work, and "Singin' in the Bathtub" by Michael Cleary, Herb Magidson, and Ned Washington. Invoking the pathos topic in a similar way to Fiddling Around, "Träumerei" is played diegetically by a wandering fiddler to transform an aggressive barking dog into howling and crying subservience, as if to invest the emotional content locked up in music of this kind with the power of a form of weaponry that manipulates and subjugates its innocent, impressionable victims: a neat summation of what some might describe as the function of music in the real-world context of golden-age Hollywood film consumption. Notably as the dog later attempts to get its revenge but becomes trapped in the path of an onrushing train, the fiddler relents, saves its life, and the two figures are reconciled, albeit as master (purveyor of popular and classic culture) and faithful servant (consumer of the same).

I Love to Singa (1936), a parody of Al Jolson's The Jazz Singer using a song from the Jolson film The Singing Kid (1936), plays more blatantly on the high-low cultural distinction, in a markedly Yiddish context of family interactions and vocabulary. It employs "Träumerei" diegetically as archetype of highbrow classical music when an owl hatchling immediately strikes up the tune on his violin to the approval of his strict music-teacher father (Prof. Fritz Owl) who has banned jazz from the house. Hailed by the father as "a Fritz Kreisler," the hatchling is preceded by an operatic sibling singing an aria from Donizetti's Lucia di Lammermoor and followed by another playing Mendelssohn's "Frühlingslied" on the flute, respectively greeted as "a Caruso" and "a Mendelssohn." By the end of the narrative this parental musical prejudice is finally overturned on the basis of the commercial success of the popular music style practiced by a fourth, renegade, hatchling vocalist named Owl Jolson, and through the father's eventual willingness to sacrifice "high" aesthetic principles for the sake of familial unity. In other words, social cohesion is portrayed as dependent on the embracing of popular culture and on becoming 
part of a mass consumer marketplace, in this case represented by Owl Jolson's success on the radio. The question remains as to whether the abandonment of "old world" values in this intergenerational conflict should be interpreted as exacerbating or negating what by the turn of the century, Levine suggests, was an already "exaggerated antithesis . . . between the aesthetic and the Philistine, the worthy and the unworthy, the pure and the tainted." 69 Taking into account the significant historical context of the film being parodied here, the program of music on display was almost certainly intended to echo, and perhaps also to celebrate, crucial events in the advent of film sound that had occurred a decade before the cartoon's release, and whose epoch-making repercussions would still have been felt by audiences. In 1926, a year before the appearance of Jolson's film The Jazz Singer, Warner Bros. gave the first public demonstration of their Vitaphone sound-on-disc system in New York. The program featured a series of shorts containing musical performances of well-known classics and vaudeville items: Wagner's Tannhäuser Overture (New York Philharmonic), Dvořák's Humoresque (Mischa Elman, violin), Verdi's aria "Caro nome" from Rigoletto (Marion Talley, soprano), popular and vaudeville numbers by a Russian troupe of dancers, the guitarist Roy Smeck and the singer Anna Case, variations on Beethoven's "Kreutzer" Sonata (Efrem Zimbalist, violin), and Leoncavallo's aria "Vesti la giubba" from Pagliacci (Giovanni Martinelli, tenor). ${ }^{70}$ Another account of the program even lists Fritz Kreisler among the artists, as well as Jolson himself performing "Rock-a-Bye Your Baby with a Dixie Melody" in a filmed vaudeville sequence called "A Plantation Act." "71 The path toward cinema's subsumption and collective popularization of the cultural spectrum had begun to be trod.

\footnotetext{
${ }^{69}$ Highbrow/Lowbrow, p. 232.

${ }^{70}$ See James Wierzbicki, Film Music: A History (New York: Routledge, 2009|, p. 91.

${ }^{71}$ Michael Freedland, "You ain't heard nothing' yet: How one sentence uttered by Al Jolson changed the movie industry," The Independent, Friday, 28 September 2007 http://www.independent.co.uk/arts-entertainment/films/ features/you-aint-heard-nothing-yet-how-one-sentence-uttered-by-al-jolson-changed-the-movie-industry464743.html, accessed September 2010.
}

The host of the radio talent show featured in I Love to Singa, on which Owl Jolson achieves fame, is named Jack Bunny in obvious homage to one of America's best-loved comedians, Jack Benny. By the end of the 1930s Benny was an established radio star, with programs for CBS and NBC that would last into the mid-1950s (and beyond in repeat broadcasts). His miserly, self-satisfied comic persona was in large part built on an early vaudeville career (ca. 1911-21) as a violinist in a duo act at one time called "From Grand Opera to Ragtime." He would subsequently gain considerable comic mileage from mocking his own classical training through pretentious claims of talent or simply by playing extremely badly. He thus contributed to a significant strand of comedy performance that persisted in various guises well into the late twentieth century, and indeed was a fundamental aspect of early film-music practice. ${ }^{72}$ One of the most gratuitous attempts in goldenage animated film finally to demolish high art pretensions is made in the Jack Benny spoof Malibu Beach Party (1940), in which the comedian entertains Hollywood greats at his house only to ruin the party and force guests to leave with his own "diegetic," "soured" violin-andpiano version of "Träumerei" with excruciatingly bad tuning. The very power of emotive Romantic repertoire to subjugate-a power so closely associated with this piece-is pilloried here, as the wretchedness of the performance debilitates the music, making it necessary for the Jack Benny character to pin down his minstrel-like black servant Winchester to the floor: "Someone's going to listen to this. Isn't this number beautiful, Winchester?," to which Winchester replies "under the circumstances, yes." The blackface of Jolson and the entire history

\footnotetext{
${ }^{72}$ In the work of, for example, Dame Florence Foster Jenkins, Victor Borge, Peter Schickele as P. D. Q. Bach, and in the United Kingdom, Les Dawson, the Portsmouth Sinfonia, and Morecombe and Wise. Victor Borge ends one of the stage performances from the latter part of his career with a rendition of "Träumerei," complete with comic interjections, the occasional added chromaticism, and an extra concluding flourish (viewable at: http://www.youtube.com/ watch? $\mathrm{v}=\mathrm{qdmEg} 5 \mathrm{DCawU} \& \mathrm{p}=\mathrm{D} 4 \mathrm{ADD} 2 \mathrm{E} 6 \mathrm{D} 162 \mathrm{E} 095$ \& playnext $=1$ \&index $=17$ ). Winkler describes the practice of playing well-known wedding music out of tune for scenes of marital conflict or divorce as "souring up the aisle" (cited in Altman, Silent Film Sound, p. 361).
} 
of minstrelsy echo through the Winchester character and lend a problematic racial dimension to the notions of subjugation and acquiescence, which would resurface only in the most recent usage of the Schumann piece in Beyond Borders (2003), discussed below. But perhaps there is yet another level of cultural meaning present here. If already in 1915 Ernst Luz was questioning the effectiveness of multiple repetitions of "Träumerei" in film accompaniment, then by 1940 the piece was, at least partially, shifting in public perception from being a well-loved classic to becoming hackneyed and clichéd. Through the cynical lens of its Benny character, Malibu Beach Party is as much deriding the music's status as over-used and thus enfeebled formula in screen media, as it is attacking the posturing of the classical music aesthetic it might represent. The problem of affective fatigue in the use of the music intensified during the course of the twentieth century, though, as we have seen and as discussed below, certain types of usage nevertheless succeeded in releasing the considerable potential cultural energy stored up within music as cliché.

Into the "self-referential" category fall two examples that, in their different ways, encapsulate the complexity of the aesthetic, cultural, and historical situation I have been discussing so far. The Old Grey Hare (1944) has Bugs Bunny and Elmer Fudd transported to the year 2000 where, in old age, their relationship continues unchanged and from which perspective they reminisce about their first encounter as babies, when the antagonism began. In this historically synoptic account, the composer/ compiler of the score, Carl Stalling, portrays Schumann's "Träumerei" as having become deeply ingrained in the lives of these characters and, by extension, in the putative world of the cartoon in the year 2000. The hapless Elmer Fudd (virtuosically voiced by Mel Blanc), who has yet again been fooled by Bugs into thinking he has mortally wounded his nemesis, sobs at the "result" of his action (while Bugs starts to dig his own grave) in a way that precisely traces the melodic contours of the string version of "Träumerei" faintly accompanying at this point. As soon as Bugs has managed to trick Elmer into entering the grave instead, the music switches back to the familiar raglike, brassy, syncopated "Merrie Melodies" music. The traversal of diegetic boundaries, penetrating psychological areas of a character (however absurdly slapstick), is significant. The vocalization is internal to Elmer's psyche. But it also points externally both to the underscore of this specific narrative cartoon and to the wider history of cartoon practice in which use of the music had by this time become associated with acts of roguish emotional deception as humor (compare with Duck Soup to Nuts and Hare Ribbin' from the same year, and Hare Trimmed from 1953). The plot's chronological projections suggest a degree of self-reflexiveness on the part of the genre in relation to its history, which is enhanced by the headlines of the newspaper Elmer reads from the year 2000: "Bing Crosby's Horse Hasn't Come In Yet!" (a topical jibe at Crosby's knack at the time of backing poor racehorses), "Smellevision Replaces Television! Carl Stalling sez, 'It will never work!'” (a dig at the then potential emergence of home viewing as a rival to cinema).

The Hot Cha Melody of 1935 is yet more historically trenchant in its unique invocation of the ghost of the composer. ${ }^{73}$ Krazy Kat is a Tin Pan Alley music hack instructed by the devil figure that emanates from inside his own head to steal Schumann's "Träumerei," jazz it up after the manner of Al Jolson and George Gershwin, and make a hit out of it. ${ }^{74}$ Mischievously, the devil then awakens the composer's

\footnotetext{
${ }^{73}$ I am very grateful to Ivan Raykoff for bringing this cartoon to my attention, and to Daniel Goldmark for supplying me with a copy.

${ }^{74}$ As a precedent for this, and a possible stimulus for the making of the cartoon, in a 1911 Broadway revue entitled La Belle Paree Al Jolson sang a number called "That Lovin' Traumerei" whose chorus adapts the last eight measures of the Schumann original lomitting the shift to $G$ minor in the last two measures, as is the case with The Hot Cha Melody and Break of Hearts-see below). This song was recorded the following year by Jolson (Victor Record 17119. B) and is available to hear on YouTube at http:// uk.youtube.com/watch?v=HhQkeTOKO_c. Gershwin's first-known composition, dating from 1912 or 1913, was entitled "Ragging the Traumerei" and adapts the first eight measures of Schumann's original (with typical syncopations and vamping bass) for the $\mathrm{B}$ sections of its $\mathrm{ABAB}$ (plus intro and coda) structure (see Howard Pollack, George Gershwin: His Life and Work [Berkeley: University of California Press, 2007], p. 219). A recording has been made by Paul Bisaccia on The Great American Piano Revisited (Towerhill, TH-72027, 2010).
} 
ghost from a statue, which desperately screams "My music!," storms into Krazy's room and destroys numerous radios that are churning out versions of the song by various star singers (including Bing Crosby, Rudy Vallee, the Boswell Sisters, and Kate Smith). Krazy is finally chased inside the piano by Schumann who pummels him with the hammers by playing another tune, which the Kat, though literally being beaten by the tools of his own trade, eventually also declares a hit. In the end, then, there is no escape for Schumann from the appropriation of his music. At a very early stage in its history the cartoon industry is here unashamedly acknowledging and sending up its own emerging practices and those of the previous silent-film tradition, that is, of raiding the classics and playing what purists might see as the morally questionable game of appropriation and aesthetically reductive manipulation. Moreover, The Hot Cha Melody presents this within the context of a conveyor-belt music industry in which songwriters are under pressure to produce material and think nothing of stealing each other's ideas. The solution to creative blockage, dreamt up by the musician's own mental demons, proves uncontrollable and comes back to haunt its very progenitor.

There is, however, a highly significant, if fleeting, moment of ambiguity in the cartoon (at 5:19), when Schumann's ghost is standing below Krazy's window in the middle of Tin Pan Alley surrounded by neon advertisements for the "Hot Cha Melody" hit version of his piece. A series of radio performances from wellknown popular singers has just been heard. After the last of them by a scat-singing blackface minstrel, the composer can be seen briefly moving rhythmically to and almost conducting the music despite himself, momentarily dancing to the tune of the devil's commercial machinations, as it were, before clambering into Krazy's room, accusing him repeatedly: "You stole my melody, you stole my melody." Furthermore, the music that Schumann ends up playing as a physical punishment of Krazy is distinctly raglike with its four-square syncopated melody and vamping bass: a turning of the tables through a return act of theft, perhaps, or else a surrender to the still-dominant paradigm.

Although it is dangerous to speculate ana- chronistically, we are entitled to question whether any attempt to correlate early Romantic Schumannesque categories of humour, irony, or wit with the kind of comedy on display here would be fruitful. Let us recall that masquerade, role-playing, and adoption of personae were fundamental elements in Schumann's Romantic carnevalesque aesthetic whose process of dissembling both cloaked and intensified deeper realities of meaning. The twin roles of a Eusebian tendency toward sentimentality and a Florestanesque tendency toward mischievous irony in his music-the "melancholy magical allusions" of emotions that the latter then "roguishly hides"75_are also striking characteristics of the screen use of "Träumerei" as it veers between maudlin and mocking, ingenuous and cynical polarities. Cartoon absurdity derived from caricature and stereotype plays with clichés of sentimentality. Its slapstick comic context may seem somewhat blunter than Jean Paul's "learned satire," Heine's manipulation of cliché, or the sophisticated, anarchic legacy of Sternian language and narrative games. Yet it would nevertheless be illuminating to contextualize Bugs Bunny, Daffy Duck, Elmer Fudd, Yosemite Sam, Krazy Kat, Mickey Mouse, Owl Jolson, Jack Benny, and the characters from Three's a Crowd-some fictional, some real-in terms of a latter-day Commedia dell'Arte corpus of figures of the kind that, along with actual people, Schumann called upon in literary-critical contexts and musically "animated" in richly allusive fashion in Carnaval.

At first sight it might seem that in the cartoon repertoire discussed above we are confronted with a newly intensified poetics of the vulgar-a perversely romanticized mass economics of instant gratification and indulgence that grinds down and fragments the already miniature-rather than a vanguard culture with exalted revolutionary goals and challenging methods that might see the world in a grain of sand. However, Schumann himself may well have experienced some form of nineteenth-century precursor to "low" humor in the 1840s

\footnotetext{
${ }^{75}$ Eismann, Robert Schumann: Tagebücher, p. 414, cited in Heinz J. Dill, "Romantic Irony in the Works of Robert Schumann," Musical Quarterly 73 (1989), 192.
} 
fashion for vaudeville theater modeled on French comedies with popular musical accompaniments, and representative of the less exalted end of what Biedermeier culture had to offer. Furthermore, his imaginary formation of the "Davidsbund" was both a product and a subversion of Biedermeier culture and society. Schumann was aware that, as in many other Austro-German cities in the Vormärz years, the activities of any new association in Leipzig would excite the interest of political censors. Conditions were somewhat more relaxed in Leipzig than in Metternich's Vienna, adding all the more to expectations of controversy: "For many the mystery of the whole thing held a special attraction, and above all-as with anything that is disguised-a particular power," as Schumann noted of the "Davidsbund," which had become "something of a sensation" in Leipzig. ${ }^{76}$ One of his most significant targets was superficiality and empty showmanship in the form of the traveling virtuoso. Through its own, lowlier "smile at the trivialities of life," animated film of the early twentieth century (to whose plotlines masking through "dressing up" and disguise is endemic) took this same impulse and subject matter to iconoclastic levels, forcing audiences to think anew about entrenched popular classics and encouraging them to laugh in the face of ostentatious classical pyrotechnics, in a context that had a mixed potential for sociocultural and aesthetic progressiveness as well as its opposite. Whether the specific kind of souring of "Träumerei" in Malibu Beach Party or the musical and cultural parody of Fiddling Around could ultimately be said to stand for the extreme end of a spectrum of general cinematic flattening of the kind of poetic legacy that Schumann wished to bequeath in his music and writings is a question on which the use of the music in the rather differently constituted aesthetic of liveaction cinema may be able to shed further light.

\footnotetext{
${ }^{76}$ Letters by Schumann (the first quotation from a letter to Zuccalmaglio), cited in Bernhard Appel, "Schumanns Davidsbund: Geistes- und sozialgeschichtliche Voraussetzungen einer romantischen Idee," Archiv für Musikwissenschaft 38/1 (1981), 1-23; quotation 17.

${ }^{77}$ Schumann on Heine, cited in Friedrich Schnapp and Theodore Baker, "Robert Schumann and Heinrich Heine," Musical Quarterly 11 (1925), 599-616; quotation 606.
}

Live action. Live-action repertoire partially overlaps with cartoon in the function and contexts of its use of "Träumerei," but also offers distinct dimensions in its scoring practice. Between 1935 and 1948 at least seven feature films made use of the piece, including two whose subject matter was the composer himself. Four predate the Schumann biopics Träumerei (1944) and Song of Love (1947). More will be said of Break of Hearts (1935) below, but the rest, the comedy-romances We Went to College (1936) and Americaner Shadchen (1940), include relatively straightforward diegetic arrangements of the piece with romantic symbolism in the contexts of a college reunion and a wedding. In a reflection of its recent cartoon heritage, the comedy-crime-caper A Slight Case of Murder (1938) employs a comic orchestral version for trombone and strings nondiegetically, as the former gangster Edward G. Robinson checks that his rough orphan-boy ward is asleep and engages in mock-serious dialogue about the "halo" around the boy's head. Thus familiar topics of romantic attachment and dream, presented both "straight" and ironically, were present at an early stage in live-action usage.

Produced under the auspices of the then Nazi-controlled UFA (Universum Film Aktiengesellschaft), Harald Braun's Träumerei is nevertheless an entirely nonpropagandist biographical account of the composer and his relationship with Clara. ${ }^{78}$ Compared with its American counterpart, it is historically more accurate and markedly free of sentimentality and melodrama, particularly in its treatment of Schumann's mental breakdown. Indeed it displays a depth and seriousness of aesthetic reflection that sets it apart from much contemporaneous Hollywood output. Through the power of Schumann's music, Clara's performances, and their relationship, an initially intransigent Wieck is com-

\footnotetext{
${ }^{78}$ Träumerei appears to have had limited distribution in the United States in 1953, but has not been released on video or DVD and is not held in the BFI archives. I consulted a $35 \mathrm{~mm}$ copy held in the Bundesarchiv-Filmarchiv, Berlin. I am grateful to Jutta Albert and David Parrett for facilitating this viewing. According to David Cook, only about 25 percent of the feature films produced in Germany between 1933 and 1945 contain overt propagandist material (see A History of Narrative Film, p. 352).
} 
pelled to rethink his outlook. Near the beginning of the film he peruses and criticizes "Träumerei," the score of which Schumann has just presented to Clara, and which Wieck overhears her playing for the first time. Schumann asks him for Clara's hand, to which Wieck responds: "Life admits of no dreams." "But art thrives on dreams . . . it is dream" replies Schumann; Wieck: "Art and life are enemies ... forget your dreams." By the narrative conclusion, after Schumann's death, Wieck has relented: "Art is greater than life" and, mirroring Schumann's sentiments earlier expressed to Brahms ("Music is solace and dream"), he continues: "it is our solace and our duty."

Opus 15 , no. 7 is imaginatively woven into the film's opening orchestral credit sequence by the music editor Werner Eisbrenner. Its opening melodic fourth is used several times as a familiar "hook" and as the departure point for newly composed material. The first two measures of the melody later return to round off the sequence. Unlike Song of Love, but in common with almost all other screen usage of the piece (diegetic or nondiegetic), here Clara's performances are incomplete (Table 1). For whatever reason, the statement in $\mathrm{B} b$ shifting to the relative minor (mm. 13-16) is omitted on first hearing. At the very end of the film the aged Clara receives a standing ovation before describing Schumann as "the star of my life," sitting down at the piano, stating simply "Träumerei," and playing the first four and last four measures, as a kind of compressed coda or peroratio to the narrative. Just as the opening credit sequence drew us into the world of the film through its adaptations of the melody, so here underscored strings join the last phrase to frame our exit from the diegesis. The historical, personal, and creative are blended sensitively by Braun. Clara first dreams she is playing the piece to an audience at one of her upcoming Parisian concerts: "Mesdames et Messieurs, I will play the 'Träumerei' by Herr Robert Schumann" she announces, curtseying in front of the piano. At the sanatorium, his mind gone, Schumann presents a scrawled manuscript to Clara with the same announcement, whereupon mm. 1-4 can momentarily be heard on a non- or meta-diegetic piano, perhaps "projected" from his or her imagination. The overturning of Wieck's judgment is aestheticized as the overcoming of a passionless, unimaginative rationalism. If for Wieck Schumann's music is "lacking in rigour and form . . . his talent is obscure," these very qualities are celebrated by Schumann's generation as the work of "revolutionaries," in the words of the composer himself. Out of this tiny piece, or fragments of it, emerges an entire aesthetic of musical romanticism as dream-expression, which, as even Wieck is ultimately compelled to admit, transcends pain and happiness.

As its credits acknowledge, the American Schumann biopic Song of Love (1947) plays fast and loose with factual accuracy regarding the composer's relationship with Clara and her musical activities. Nonetheless "Träumerei," presented completely free of irony, interestingly provides entrance to and exit from the highly sentimentalized narrative. At the beginning, after finishing her performance of Liszt's Piano Concerto No. 1 in a public concert, she asks her father in the wings if she can play "Träumerei" as the encore, but Wieck insists that the encore will be "La Campanella." Clara nevertheless goes ahead and plays her choice, announces it as the work of a "new" composer, and afterwards explains defiantly to her father (who, significantly, accuses her of childishness) that she did it for Robert (who was in the audience) because of her love for him. Toward the end of the film, an ailing Schumann starts to play the piece for Clara in the sanatorium, claiming that he had just composed it for her. The sentiment of the performance is notably augmented by the seemingly intentional repeat of the bass $G$ at the end of m. 7, lending extra poignancy to the diminished-seventh chord above. Schumann is unable to complete the piece, however, and falls on to a harsh dissonance, an act that signifies his death. Despite the unsurprisingly hagiographic nature of the film's conventional plot, "Träumerei," which significantly is heard complete and fragmented, thus encompasses an extended range of semantic levels. It supports an ambiguous adult-child emotional axis in the reaction of Clara's father and that of the juvenile Prince in the concert audience who takes a special interest in the piece and the player. It encapsulates the bliss of the burgeoning personal relationship between 
Clara and Robert —as a kind of bulwark against parental and social disapproval. It is held to represent the simplicity and directness of a "new" kind of music set against the empty display and drama of the Liszt Concerto (however historically misconceived). It acts as a focus of individual inwardness in a public arena that has just been treated to a virtuosic exhibition, thus more closely matching the conflict between the collective and the private experience inherent to cinematic consumption. It embodies nostalgia and its inverse in loss of memory, at the end of the composer's life, through recognition of the music's significance and that of the tragic inability to complete it. Finally it symbolizes a gateway to death, the last gesture of a dying man more poignant than any verbal farewell.

For all its excesses, inaccuracies and triteness-for example, Clara only ever performed Kinderszenen in private gatherings in the 1830 s and early $1840 \mathrm{~s}^{79}$ - and with obvious regard to its status as Schumann biopic, Song of Love invokes signifying possibilities that would certainly fall within the "active" category outlined above, and that have a surprisingly high degree of complexity and subtlety within the film's romanticized narrative orbit. Since the film operates on the clear terms of romantic hero worship, the exalted but fragile nature of artistic creativity, and the biography of the work's very creator, it would be wrong to compare it baldly with the cartoon repertoire previously discussed. In general sentiment it is perhaps closest to Tom Thumb in Trouble, but what it gains in straightforward "respect" for the piece it loses in its lack of the kind of terse contemporary social critique allied to other repertoire's fields of manipulative irony through radical fragmentation, recontextualizing, and reductio ad absurdum.

Though less varied in its semantic palette, the use of "Träumerei" in Break of Hearts (1935) gives an early example of the screen medium's awareness of the multifunctional potential of a single, moderately extended, music cue. This film has a narrative similar in many respects to

\footnotetext{
${ }^{79}$ See Ferris, "Public Performance and Private Understanding."
}

that of Song of Love: Katharine Hepburn (who also went on to play Clara in the later film) is a struggling young composer-pianist who falls for and marries an eminent but somewhat rakish orchestral conductor. Problems ensue, but "Träumerei" is the music that underpins the all-important initial sealing of the relationship. In just under three minutes of screen time the mood progresses from lighthearted awkwardness to declared and fulfilled passion, and it is the treatment of the music that allows this progression to be accepted as natural. After Hepburn's character plays the opening four measures for her soon-to-be lover-this was the first piece she ever performed in public, we are told-a nondiegetic string arrangement with ubiquitous portamenti takes over with the next phrase, and he slips into reverie: "I can picture you . . . your feet hardly touching the pedals." They move closer and the intimacy develops with glowing close-ups of her face and initial physical contact. Then follow three dissolves without dialogue but smoothed over by the continuing underscore: to the inside of a taxi, to a shot of their feet walking up the steps of her apartment, and to the unlocking of her door which, after touching her hand, he does himself. Inside the apartment they briefly kiss and declare their love. Significantly, the kiss takes place just after the beginning of the third phrase from the end $(\mathrm{m} .17$, the return of the opening melody), whereupon two passing chromaticisms are added to the part-writing in order to provide a "sweetening" effect typical of Hollywood and to strengthen the anchoring in the tonic (passing $C \#$ to $D$ in the move to the subdominant chord, $\mathrm{m}$. 18, and passing $\mathrm{G} \#$ to $A$ in the move to tonic in second inversion, mm. 18-19). Whether mundanely for purely practical purposes of fitting the score to the cutting, or subtly to cement the sense of unalloyed union and interim closure, the part of the final phrase comprising the momentarily diverting chromaticized move to the supertonic $\mathrm{G}$ minor $(\mathrm{mm}$. $23-24)$ is omitted. ${ }^{80}$

Music, particularly nineteenth-century music, is the subject of this film in more ways than one. Its predominantly compiled score in-

\footnotetext{
${ }^{80} \mathrm{An}$ identical cut is made in Three's a Crowd.
} 
cludes excerpts from Schubert's Symphony No. 8, Dvořák's Symphony No. 9, Tchaikovsky's Symphony No. 5, Mendelssohn's Wedding March, Brahms's Symphony No. 1, a romanticized orchestral version of Bach's Toccata and Fugue in D Minor, and the popular song in waltz style written in 1894 by Charles Lawlor, The Sidewalks of New York. The Hepburn character's own "composition" (presumably written by Max Steiner, in the style of a turn-ofthe-century popular "classic"), which brings the couple together, permeates the rest of the scoring. It is used as a conduit for the conductor's mental recovery and a symbol of Hepburn's devotion to him at the end of the film. In the bar where he languishes in a drunken stupor, she plays it with rising intensity (accompanied by swelling nondiegetic orchestra) on the pianola that had previously been churning out a feverish ragtime. The piece opens with a rising fourth as if it will continue as "Träumerei," but unfolds in a different direction, more akin to the lightly chromaticized romantic style of Hollywood film scoring that became standard practice in the 1930s. Together with the film's wider musical repertoire, "Träumerei" supplies the context for the burgeoning narrative of human relationships, and, both diegetically and nondiegetically, it provides emotive contours, "aesthetic sealant" and place, and perhaps most important of all a catalyst for romantic attachment and devotion. As a nineteenth-century fragment that "just is, like a single gesture of the hand," 82 "Träumerei" is curiously subject to a degree of both restriction and "enhancement" in the scene in which it is used: the former aesthetically and semantically through sentimentality, emotive anchoring, and formal cuts; and the latter through extraneous musical material and through being invested with a temporality that, with the help of harmonic additives, draws more of a sense of linear architecture from the work than its cyclic, repetitive phrase openings would otherwise suggest. As Altman notes: "in order to assure its film future, music had to abandon its

\footnotetext{
${ }^{81}$ Smith, "Unheard Melodies?," p. 237.

${ }^{82}$ Raymond Monelle, The Sense of Music: Semiotic Essays (Princeton: Princeton University Press, 2000), p. 90.
}

first principles" of internal logic. ${ }^{83}$ What has replaced that logic in this instance is a specified emotional narrative to which the unfolding of the music is assigned as carefully aligned practical (diegetic) entry point, ambient (nondiegetic) mood and aesthetic backdrop extending over changes of location and the progress of romance, and repository of levels of passion depicted and felt by characters and audience. We, the couple, and the music melt as the longed-for kiss takes place-a consummation that causes, as much as it is reflected by, the chromatic alterations to the harmony.

For those who subscribe to a strict Schopenhauerian view of the noumenal nature of music, the repercussions of this are potentially vast: nothing less than an overturning of the idea of Romantic musical transcendence, a debunking of the myth of the metaphysics of absolute music and the primacy of instrumental music, and a denial of music's "domain of the infinite" and "nameless longing" accessed through disinterested contemplation of its autonomous nature. While film might be accused of dealing in, indeed relying upon, the complete contingency of music, for adherents to programmatic thinking or a belief in music's thorough sociocultural entailment and mediated nature, this very contingency is what gives music its power and significance. The cinematic use of "Träumerei" would in this case offer another, albeit more explicit and determined, kind of fanciful, inventive engagement with music's expressive meaning, general mood, or atmosphere: "Unconsciously along with the musical image an idea continues to operate along with the ear, the eye; and this, the ever active organ, perceives among the sounds and tones certain contours which may solidify and assume the shape of clear cut figures," as Schumann explained the compositional process, whose aesthetic points ahead to the multiple modalities of cinematic perception. ${ }^{84}$ In this sense, film merely supplies sets of associations equivalent in kind to, though not necessarily precisely matching, the imaginative responses

${ }^{83}$ Silent Film Sound, p. 243.

${ }^{84}$ Schumann, cited in Brown, The Aesthetics of Robert Schumann, p. 163. 
the composer considered a natural and legitimate part of the music-listening experience, especially in the case of Charakterstücke such as those that make up Kinderszenen. The only questions that remain are, if through force of exposure we predominantly or only perceive the films' images whenever we encounter the music, does this amount to a degradation of the latter's aesthetic properties? And if film is "putting words into our mouths" by putting them into the "mouth" of the music, does this diminish the depth and latitude of our free-floating imaginations? We may be in a better position to address these questions after the current examination of "Träumerei" in cinema is pursued to more recent manifestations of the practice.

On the back of Song of Love, M-G-M produced Big City the following year (1948), a deeply sentimental forerunner of Three Men and $a$ Baby in which the great German soprano and recent star at the New York Metropolitan Opera, Lotte Lehmann, plays a sweet-natured Jewish grandmother figure helping to nurture an abandoned baby. Having sung a version of Brahms's Lullaby to the child in the early part of the film, she later sings along wordlessly to an arrangement of "Träumerei" for piano, cello, and concertina played during a brief musical soirée by the three men who had first stumbled across the foundling. By this stage in the film the child in question has reached the age of twelve, and various layers of allusion and homage in the performance may be inferred: from a noted German émigré, then resident in Santa Barbara, to her European cultural heritage; to the late-nineteenth-century Hausmusik legacy of chamber-ensemble arrangements of the work evidenced by the Simon publication cited above, and destined for intimate musical occasions such as that depicted here; from the caring female character to her past role as the "materfamilias" in bringing up the lost child; and to the unifying power of music and childhood embedded in the work, which transcends the religious and cultural differences between the Jewish, Protestant, and Catholic protagonists. The piece is sampled (only the first and last phrases of the piece are heard), while the camerawork poignantly shifts ever closer to Lehmann during the scene from a wide general shot of all, to a medium shot of the three female characters (Lehmann, child, and the love interest of one of the men), to a close-up of Lehmann's earnest face. The scene's prioritizing of music as emotive cipher over the preservation of its work-centered structural integrity provides yet further substantiation of Altman's claims.

Interest in "Träumerei" waned somewhat in later postwar years, and after 1953 it does not seem to have been used again until 1972 and is thereafter present in only seven more films. Perhaps it was a sign that exhaustion of the music's first-level aesthetic and semantic capabilities had finally set in: "Träumerei" could not escape the identity it had assumed as cliché, and even the power invested in this cliché was diminishing. Its absence may also have resulted from the rise of the specially composed film score during the Hollywood golden era, as well as subsequent decreasing interest in European classical music as both stylistic model and preexistent score in favor of popular music styles and repertoire during the post-studio systemall of which pushed film music in different directions. The art-film circuit may have chosen to steer clear of its hackneyed associations, and where it does appear, its use is often no more than a pale imitation of earlier conventions. For example, Visconti's Ludwig (1972) places "Träumerei" within a predominantly Wagnerian score in a passage near the beginning of the film with other movements from op. 15. The troubled Ludwig is walking at night through a snowbound Bavarian park with his cousin Sissi, with whom he appears to be in love. "Träumerei" steals in when the conversation begins to get personal, but the performance, though on piano, is strangely altered: the melody is stripped of some of its arpeggiation, and alterations are made to the melodic contour in $\mathrm{mm} .6,7,10$, and 11 . Some of these changes introduce Schumann-like appoggiaturas, for example, a 4-3 (F-E) over chord $\mathrm{C}_{4}^{6}$ in $\mathrm{m}$. 73 , a 4-3 (C-Bb) over chord $\mathrm{Gm}$ in $\mathrm{m} .11^{1}$, and a 9-8 (A-G) over chord $\mathrm{Gm}_{4}^{6}$ in $\mathrm{m} .11^{3}$-which serve all the more to highlight the relatively subdued levels of dissonance in the original. The performance is rhythmically very erratic, as if improvised, and the overall effect is oddly detached, as if Schumann's music were little more than 
an unremarkable, absentmindedly doodled and embroidered salon piece for the aristocratic classes, which has a degree of historical veracity for the $1860 \mathrm{~s}-80$ s period of the film's setting. Schumann's piece accompanies the onset of possible courtship and is set against Wagner's music, which is employed for the "real" passion, drama, and tragedy of subsequent events. Such aesthetic distinctions are not particularly favorable to Schumann, but given the film's subject matter it could perhaps hardly have been otherwise.

Because they partake in modes and contexts of usage very similar to those of the repertoire previously discussed (a fact significant in itself), most of the remaining live-action films may be dealt with briefly. Madame Sousatzka (1988) is a reworking of the struggling musician story in which the young pianist strikes up "Träumerei" at a dinner party to the rapt attention of his entourage. It acts as confirmation of the budding musician's artistic depth and value. Schumann's Piano Concerto also marks the musician's controversial public debut against the wishes of his eccentric and overbearing teacher. Tea with Mussolini (1999) follows the grief and mourning theme by having the piece played on solo violin during a ceremony of remembrance at the tomb of Elizabeth Barrett Browning in Florence. This happens while the eccentric art lover played by Judi Dench flamboyantly recites one of her poems, and the scene is intercut with shots of the unwanted child at the heart of the story. Recourse to the music in a 1930s European setting such as this reflects a degree of historical accuracy regarding the piece's reception history both in the real world of that time and in films made during that period, enacting a kind of double homage. Moreover, the style and mood of the much-heard principal theme of the composed score by Stefano Arnaldi and Alessio Vlad, mostly used to symbolize the high-art culture, art, and spirit of the city, are clearly modeled on the Schumann piece. Mike Figgis's fragmented, parablelike The Loss of Sexual Innocence (1999) plays obliquely on the theme of childhood, and, taking the realist tendency to its logical conclusion, it uses the original piano version for an extended shot of new-born twins wriggling and twitching on a bed. The scene shifts to the courtyard of an Italian maternity center run by nuns, with images of parents cradling children, and finally to the opening of a storyline that will concern the chance meeting of two identical twins, now adults, who were separated at birth. The destruction of naivete and innocence is a strong theme in this film, manifested in primeval scenes of Eden and the subsequent brutal humiliation and shaming of the Adam and Eve figures. "Träumerei" thus adopts its inherited role of serene cradle song and the embodiment of purityharking back to Big City and further to the 1924 Rapée compilation-within the disjointed, collagelike narrative. Crush (2001) trades on infancy, dream topics, and an identical comedic aesthetic to that of much previous cartoon usage, by using a fragment of the piece to accompany a brief flashback to a daydreaming moment of one of the young, single, female protagonists during which she wistfully fondles baby clothes in a shop. In the face of the possible decline in the piece's force as cliché, it is interesting that even after a long history of exposure, its sudden interjection and abrupt dismissal within a suitably ironic setting retain the ability to draw on the EusebianFlorestanesque dialectic. With its diegetic swing-band version of "Träumerei" - a manifestation of the long-practiced popularizing aesthetic-Swing (2003) echoes Gershwin, Jolson, The Hot Cha Melody, and the early 1940s bigband practice of performing arrangements of the classics. ${ }^{85}$ The film also invokes the dream topic, in that the music is embedded within a curious semifantasy tale of a young man's dance tutelage under a mysterious guardian angel from a previous era. Finally, Wasabi (2001) simply calls on the piece as emblem of classic, latenight dinner music underpinning connotations of a relationship that either once was or could never be, all amid ostensibly alien contexts of high-octane cop action, though its use carries faint traces of the piece's long-held connotations of romantic attachment.

\footnotetext{
${ }^{85}$ Both Claude Thornhill (1941) and Glenn Miller (ca. 1940) recorded big-band arrangements of "Träumerei."
} 
Belying potential signs of fatigue in the music's recycling and emergent over-determination, the scoring tradition has continued most recently in the quasi-political romantic-epic, Beyond Borders - a film that suggests that the viability of the aesthetic, narrative, and semantic screen legacy of "Träumerei" may not be easy to sustain. ${ }^{86}$ As within the wider history of cinema, the piece runs like a silver thread through a narrative that in this case teeters dangerously close to the edge of exploiting thirdworld suffering, and culminates in an emotive rendering of the child-as-embodiment-of-lostinnocence/idealism topic. The heroine (played by Angelina Jolie) plays it diegetically (but, as in some previous examples, always as incomplete excerpts from the first and last phrases) both in her London home and, implausibly (like Juliette Binoche's famous Bach playing in Minghella's film The English Patient), in the middle of war-torn Ethiopia. It underpins her earnest voiceovers about "self-discovery," "destiny," and ethical concern for the state of the world-admirable qualities countered in the film's narrative by a tendency toward spoonfeeding in the delivery of ideas and in the dramatic presentation. The piece catalyses her relationship with a passionate humanitarian (played by Clive Owen), whom she follows around the world's troubled regions dispensing salvation. Recalling the potentially problematic sociopolitical implications of Malibu Beach Party's comedic ending, Beyond Borders makes certain awkward presumptions about the culturally and ethically superior white, middleclass European redemption of, in this case, an Africa represented as chaotic, corrupt, and violent. "Träumerei" is heavily invested with all the serenity, civilized refinement, and purity that the target country lacks, and at the same time retains its common usages as signifier of romance and childhood, a multiple freighting

${ }^{86}$ "Träumerei" has since been used in the Japanese film Bizan (2007), which I have been unable to consult. The story involves the reconciliation, through shared memories, of a daughter with her terminally ill mother-suggesting that moments of tender affection, nostalgia, loss, or images of childhood are likely opportunities for its use of the music. of specifics and universals that contributes to the narrative's strain to convince and to escape sociocultural stereotyping.

At the end of the film, for example, after the murder of Jolie's character in Chechnya, Owen's character seeks out their child daughter whom he has never seen, only to find her playing the piece on the same piano, with some textural simplification of the already simple in deference to her physical limitations, ${ }^{87}$ but more strikingly with impeccable, improbable maturity of phrasing, touch, and expression, far in advance of her mother's performances. Thus the child appears to ventriloquize the dead parent, as if both mirroring Schumann's own creative regression: "I've put on my frilly dress and composed thirty cute little things from which I've selected about twelve and called them 'Scenes from Childhood'," 88 and chiming with the composer's belief that "in every child there is a marvellous profundity." 89 But following the imperative of narrative completion, in this scene, the child, as surviving relic of the dead parent, appears to realize, more than to promise, "unlimited potentiality," a "prematurely adult" child born of a failed grown-up world-perhaps a "precocious fruit" that "will not be long in rotting." same ultimately be said of the cinematic reprocessing of "Träumerei" as well?

\footnotetext{
${ }^{87}$ Some large spans are avoided and inner parts omitted in m. 3 (left-hand Cs, right-hand E beats 2-3, left-hand F-G beat 4, right-hand $\mathrm{E}$ last eighth note), and $\mathrm{m} .4$ (right-hand F first eighth note), m. 22 (left-hand low G and B).

${ }^{88} \mathrm{~A}$ comment from 1838, cited in Kramer, "Rethinking Schumann's Carnaval," p. 106

${ }^{89}$ Cited in Starobinski, "Les Kinderszenen," p. 361.

90"Grenzenlosen Bestimmbarkeit"; Schiller, "Naive and Sentimental Poetry" (1795-96), cited in Linda M. Austin, "Children of Childhood: Nostalgia and the Romantic Legacy," Studies in Romanticism 42/1 (2003), accessed online, August 2010 at: http://findarticles.com/p/articles/ mi_hb297/is_1_42/ai_n29025321/

91"Nature wants children to be children before being men. If we want to pervert this order, we shall produce precocious fruits which will be immature and insipid and will not be long in rotting. . . . Childhood has its own ways of seeing, thinking, and feeling which are proper to it. Nothing is less sensible than to want to substitute ours for theirs" (Jean-Jacques Rousseau, Emile: or, On Education [1762], ed. and trans. Allan Bloom [New York: Basic Books, 1979], p. 90).
} 
Conclusions: Cultural Pessimism AND ITs Discontents

During its cinematic life, then, "Träumerei" seems not to have become "the music of the specific movie scene rather than the piece one may have known before," as Claudia Gorbman describes the fate of the preexistent music in Kubrick's 2001: A Space Odyssey.92 Nor does the piece revel in the postmodern "pleasures of ambiguity," as Mike Cormack characterizes the use of classical music in general in film. ${ }^{93}$ Instead, in a kind of reverse hermeneutics it seems to be conscripted by cinema primarily as clichéd fragment to fulfill a limited, predetermined semantic duty; to be enlisted to "channel the film's narrative and expressive elements into a safe harbour of meaning" (the function of all music in classical film according to Gorbman ${ }^{94}$ ); and to serve an unchallenged and unchallenging need for disambiguation. Not needing to be able, equipped, or concerned to see potentially a "whole world of aspiration" contained within the work's small frame, 95 commercial film through its very nature has tended to act as domineering foster parent to this piece: from different perspectives both a confirmation and a denial of Schumann's belief that the cultural phenomenon of music, unlike the more concrete fields of science and poetry, is "the orphan whose father and mother no one can determine." ${ }^{\prime \prime 6}$

Part of the unavoidable nature of its assumption into collective, multimedia consciousness is that "Träumerei" has thereby been compelled to travel the path from intimate, well-formed, and semantically free-floating miniature at the

${ }^{92}$ Claudia Gorbman, "Ears Wide Open: Kubrick's Music," in Changing Tunes: The Use of Pre-existing Music in Film, ed. Phil Powrie and Robynn Stilwell (Aldershot: Ashgate, 2006), pp. 3-18; quotation p. 4.

${ }^{93}$ See Mike Cormack, "The Pleasures of Ambiguity: Using Classical Music in Film," in Powrie and Stilwell, Changing Tunes, pp. 19-30, esp. pp. 19, 20, and 29.

${ }^{94}$ Gorbman, "Ears Wide Open," p. 4.

${ }^{95}$ Joan Chissell, Schumann Piano Music (London: BBC, 1972), p. 48.

${ }^{96}$ Cited in Lydia Goehr, "'Music Has No Meaning to Speak of': On the Politics of Musical Interpretation," in The Interpretation of Music: Philosophical Essays, ed. Michael Krausz (Oxford: Clarendon Press, 1993), pp. 177-90; quotation p. 180 . center of an integrated collection, to segregated, mostly abridged or fragmented, object of mass exposure and semantically determined consumption. Through a literalistic and narrowly metonymical conception of the function of titles, ${ }^{97}$ the music's subtle structural-aesthetic qualities as a small physical whole with potentially expansive horizons of meaning have usually been asked to bear the weight of prescriptive, shorthand associations. This might at least toy with the kind of debasement of music's power that Schumann feared, and as consumers we have been asked, and have largely agreed, to acquiesce. Not unlike the Adagietto from Mahler's Fifth Symphony, "Träumerei" has attained a public profile and a cemented identity of seemingly irreversible common currency that extend even to the aridity of state occasions: brass arrangements were played in Red Square at the funerals of Breshnev (1982) and Molotov (1986), for example, and with a possible note of irony Margaret Thatcher was "welcomed" by it on a state visit to Moscow during the 1980s. To this day instrumental and vocal recordings of the piece are continually played at the Piskaryov Memorial in St. Petersburg and the huge Mamayev Hill Memorial to the Battle of Stalingrad in Volgograd, near to the eternal flame and during ceremonies of the changing of the guard, harking back to the widespread adoption of "Träumerei" in Russia as a theme of dignified suffering upon the surrender of Germany in $1945 .{ }^{98}$ On the work's 150th anniversary Werner Klüppelholz felt compelled to suggest: "This piece was a protest against the empty noise of virtuosity; the expression of a poetry that was only graspable in music; a fruitful appropriation of Bachian polyphony; never, how-

\footnotetext{
${ }^{97}$ As Neil Strauss points out, Carl Stalling "employed musical puns by using popular songs [and classical numbers] whose titles fit on-screen gags, sometimes for no more than four seconds" ("Tunes for Toons: A Cartoon Music Primer," in The Cartoon Music Book, pp. 5-13; quotation p. 8).

${ }^{98}$ Excerpts of these events can be viewed at: http://

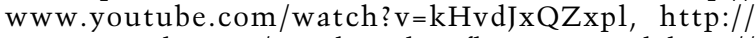
www.youtube.com/watch? $\mathrm{v}=\mathrm{dtVLfbAJY} 9 \mathrm{M}$ and http:// www.youtube.com/watch? $v=B R N f a f 4 w L N Q$. The emotionally charged performance of "Träumerei" as an encore in Vladimir Horowitz's first recital in Russia (1986) after many years of exile gives further indication of the piece's signifi-
} cance for this nation. 
ever, a sweet little panorama of the Biedermeier nuclear family. Burdened with kitsch vulgarity like a lead weight, 'Träumerei' has plunged ever deeper into the mire of the music of attractions." 99 Schumann's musical subjectivity "of solitary intimacy," of the "imprisoned soul that speaks to itself"100 is from one point of view especially vulnerable to coagulation through the placement of a piece such as "Träumerei" in the mass culture and carnival economy of the cinema. Taking this line of argument further, the Romantic ideal of the "child's" voice, protected and moralized through adult eyes, may consequently become hardened or demoralized through a premature self-sufficiency it is not equipped for. As a result the rare kind of innocence attained through maturity discussed by Barthes, the intricate mode of "studied naivety" described by Daverio, ${ }^{101}$ may be lost or submerged. According to Barthes in the late 1970s, during the fallow period of cinematic usage, "loving Schumann . . . is in a way to assume a philosophy of Nostalgia or . . . Untimeliness." 102 Cinematic appropriation may be just the latest manifestation of a merchandising trend that began in the nineteenth-century Hausmusik tradition, but the former has been apportioning Schumann's music through the channels of a twentiethand twenty-first-century globalized economy for considerably longer and with substantially more vigor than the latter. Timeliness thus enforced occurs at its own kind of expense and produces its own kind of nostalgia too. Indeed, wherever the remnants of comfortable Biedermeier sensibility and sensationalist late-Romantic myth-making combine with safe cultural and financial economies of screen industries, and the creative results that employ this music marginalize a culturally progressive, profound, and hard-won naivete of the sort embodied by

\footnotetext{
99"Reise um die Welt in 32 Takten," Die Zeit 8 (19 Feb. 1988), 41, accessed in August 2008 at http://www.zeit.de/ 1988/08/Reise-um-die-Welt-in-32-Takten.

${ }^{100}$ Roland Barthes, "Loving Schumann," in The Responsibility of Forms: Critical Essays on Music, Art and Representation, trans. Richard Howard (New York: Hill and Wang, [1979] 1985), pp. 293-98; quotations pp. 293 and 294.

${ }^{101}$ Daverio, Nineteenth-Century Music, p. 67.

${ }^{102}$ Barthes, "Loving Schumann," p. 298.
}

Alfred Brendel-who among other things insisted that the piece can only be adequately interpreted through artistic maturity ${ }^{103}$ - then we might concur that "the hour of "Träumerei"s birth, a propitious moment of inspired genius" can indeed always be seen to have marked "at the same time the beginning of its death agony." 104

But now let us awake from this nightmare. Does the recurring dream of film's use of "Träumerei," which seems to have reached a plateau since the time of Barthes's statement, present, like the repeat offending of long-corrupted youth, an insurmountable obstacle to rehabilitation? Is this very question the wrong one to ask? Are we not doing a disservice to the world of cinema that will more often than not fall short if judged by the fin-de-siècle aesthetic yardsticks that articulate the high/low, pure/ impure antithesis that has "unquestionably colored our view of culture ever since."105 Yes, the endless repeatability of film's mechanical reproduction certainly makes it difficult to resist the conditioning and congealing imposed by its frozen epic retelling. Yet if this does not preclude, but may even engender, the desire to accept and seek different kinds of historical remembrance and meaning that might reconnect more intimately with music's past and reinvest the structural processes and aesthetic qualities, even of a miniature like "Träumerei," with the rich philosophical illumination at the heart of Schumann's aesthetic program, then surely this is all to the good. Indeed we might do well to bear this in mind in the noncinematic contexts of repeated concert or audio recording consumption, which carry their own risks of musical stagnation. If, as one of the animated genre's most convincing advocates admits, the collage scoring technique of Stalling can be labeled "postmodern" because "by necessity [it] leaches much of the historical significance out of a given piece," ${ }^{\prime 106}$ it is also true that such a musical universe "achieves a special inti-

\footnotetext{
${ }^{103}$ See Alfred Brendel, "Der Interpret muß erwachsen sein: Zu Schumann's 'Kinderszenen'," Musica 35/5 (Sept.-Oct. 1981), 429-33.

${ }^{104}$ Klüppelholz, "Reise um die Welt in 32 Takten," p. 2.

${ }^{105}$ Levine, Highbrow/Lowbrow, p. 232.

${ }^{106}$ Goldmark, Tunes for 'Toons, p. 108.
} 
macy with the listener who can name a tune and get the thematic reference . . like Ives's, [this musical universe] is expansive: high and low culture, the abstract and the concrete, are brought together as part of the shared experience of composer and listeners."107 From both perspectives we are inexorably led toward different modes of understanding. Among these might be the desire to recapture something of the history that appears to have been compromised, or to relocate meaning in other ways, to dissolve cultural hierarchies by seeing one set of assumed values through the lens of its "other."

The "recitative" passages in the final movement of Kinderszenen represent an extreme moment of that mute eloquence in which, typically of much Romantic repertoire, instrumental music strains to transcend its nonverbal frame. As Michel Chion suggests, "Romantic music for piano, particularly that of Chopin, Schumann, and Liszt, is, in fact, often similar to the voice of someone humming a poem or a melody with mouth closed: a melody with unheard words." 108 Whether actually vocalized, as in the strikingly dissimilar cases of Elmer Fudd and Lotte Lehmann, or whether remaining non-

\footnotetext{
${ }^{107}$ Kevin Whitehead, "Carl Stalling, Improviser, and Bill Lava, Acme Minimalist," in The Cartoon Music Book, pp. 141-50; quotation p. 145.

${ }^{108}$ Michel Chion, "Mute Music: Polanski's The Pianist and Campion's The Piano," in Beyond the Soundtrack, pp. 8696; quotation p. 90.

vocal, cinema's "Träumerei" thwarts some avenues while revealing new ones, only to reopen the previously expected in an ongoing cat-andmouse game of reception, deception, and reconception. While the same may not be claimed for every example of onscreen preexistent music, one is nonetheless conceivably faced with a vast set of unexplored musicocultural trajectories that might well have equally moving stories to tell.

\begin{abstract}
.
Schumann's music took its place alongside that of many other nineteenth-century composers in the lexicon of silent-film accompaniment. Evidence of early-twentieth-century scoring practices indicates that "Träumerei" quickly proved to be an especially popular choice for scenes of pathos and romance. This appropriation is viewed in the context of the piece's general reception history and the tradition of its concert performance in isolation from the rest of op. 15 (and in any number of instrumental arrangements) that had come to a peak at this time. The assumption of "Träumerei" into the world of film is explored with reference to the aesthetics and changing cultural economies of Schumann's own compositional activities, the nineteenth-century Biedermeier Hausmusik tradition, and the "child" topos. The emergence of a "Träumerei" protocol in film scoring is uncovered in an examination of its continued appearance in animated and live-action sound cinema from the 1930s to the present day. The risks of semantic impoverishment of the music through clichéd film usage are assessed. Keywords: Schumann, Kinderszenen, "Träumerei," cinema, preexistent music
\end{abstract}

